\title{
MADONNA INN: A HOTEL IN CONTEXT
}

\author{
A Thesis \\ presented to \\ the Faculty of \\ California Polytechnic State University, \\ San Luis Obispo
}

\author{
In Partial Fulfillment \\ of the Requirements for the Degree \\ Master of Arts in History \\ by \\ Galadriel Bree Highhouse \\ December 9, 2011
}


(C) 2011

Galadriel Bree Highhouse

ALL RIGHTS RESERVED 


\section{COMMITTEE MEMBERSHIP}

TITLE: Madonna Inn: A Hotel in Context

AUTHOR: Galadriel Bree Highhouse

DATE SUBMITTED: December 2011

COMMITTEE CHAIR: Matthew Hopper- Assistant Professor of History

COMMITTEE MEMBER: George Cotkin-Professor of History

COMMITTEE MEMBER: Paul Hiltpold-Professor of History 


\section{ABSTRACT}

\section{Madonna Inn: A Hotel in Context \\ Galadriel Bree Highhouse}

This paper examines the political, economic and social influences that contributed to the development of the Madonna Inn in San Luis Obispo. I provide a brief history of the hotel industry and place the Madonna Inn within the historiography and argue that the nexus of three elements in the 1950s and 1960s led to the growth and popularity of the Madonna Inn: fear of nuclear war, growth of the middle class, and the rise of automobile culture in America. 


\section{ACKNOWLEDGEMENTS}

First and foremost I would like to acknowledge my family for their continual support through this project. Without their constant help and love this work would not be possible. I would also like to thank Professor Hopper who helped me focus my work to make it more concise and led me to a subject matter that I had not considered before speaking with him. I would also like to thank all of the professors who I have learned from during my time at Cal Poly; all of whom have taught me a great deal and assisted me in achieving my goals. Finally, I would like to thank my wonderful husband Jeremiah and my beautiful son Elisha who gave me a reason to complete my thesis. 


\section{TABLE OF CONTENTS}

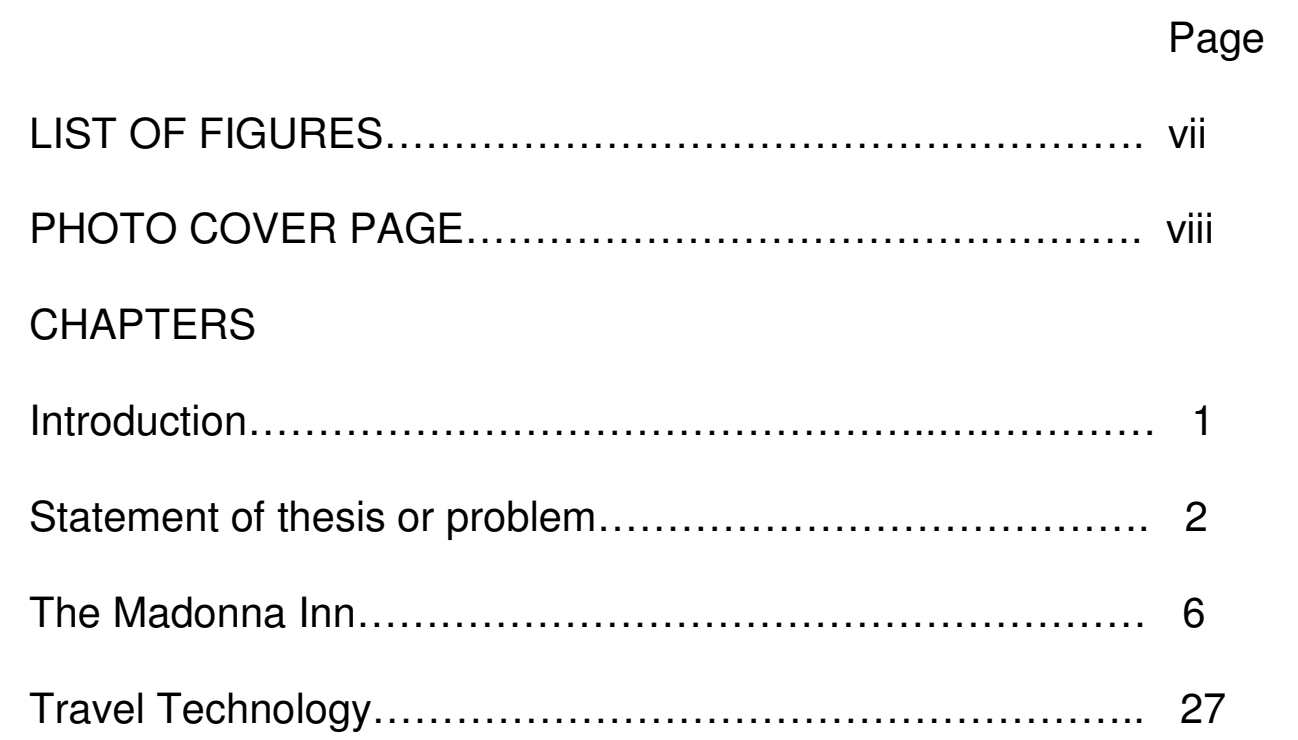

Escapism: Avoiding the Fear of the Unknown through Travel. 38

Rise of the Middle Class and its Effect on the Travel Industry. 46

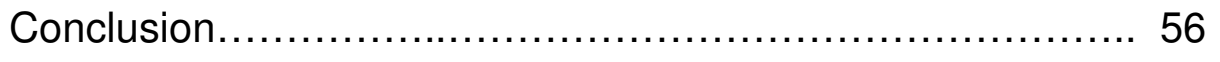

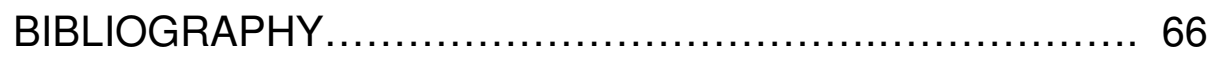




\section{LIST OF IMAGES}

Image

$\underline{\text { Page }}$

1. Portrait of Alex Madonna located in the entrance of the Madonna Inn lobby. viii

2. The tree light fixture in the Gold Rush Steak House created out of recycled material. Here the decorations are for the summer season.

3. The marble balustrade in the Madonna Lobby given to Alex Madonna by the Hearst family

4. Local boulders used to construct the fireplace in the entryway of the Madonna Inn

5. The cantilevered rock above the Copper Café

6. Example of the woodwork in the bar of the Madonna Inn which was constructed on site by Alexander Zeller.

7. The Pink Champagne Cake of the Madonna Inn and directly to the right a partial view of the Black Forest Cake...

8. and 9. The world-famous men's bathroom in the wine cellar which features the waterfall urinal and sea shell washbasin.

10. The woodwork in the women's bathroom of the Copper Coffee Shop which states "your beauty is your smile" above the mirror.

11. The copper sink and water pump in the men's bathroom of the Copper Coffee Shop.

12. and 13. The former 76 Union Oil Company gas station at the Madonna Inn. Currently the building houses a gourmet wine and gift shop. 


\section{Madonna Inn:}

Development of a Hotel in Context.

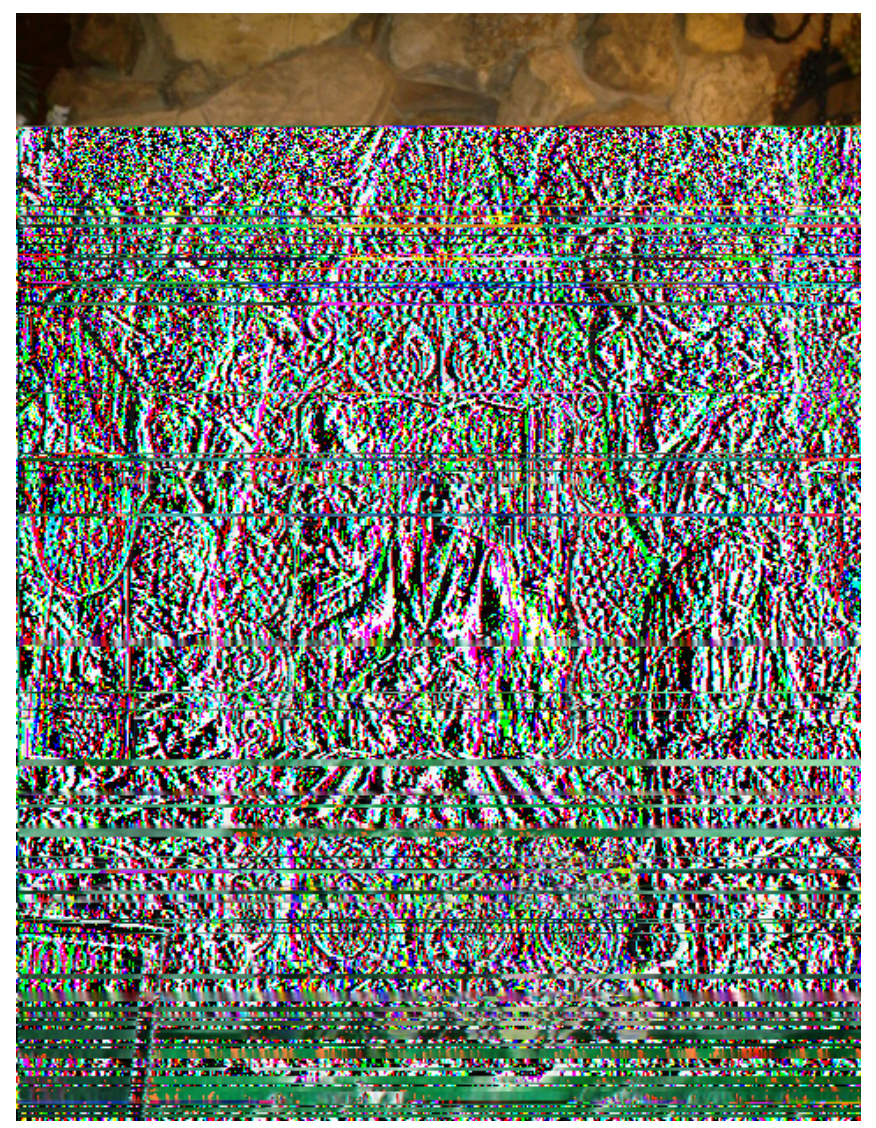

Figure F1: Portrait of Alex Madonna located in the entrance of the Madonna Inn lobby. 


\section{$\underline{\text { Introduction }}$}

As one travels northbound or southbound on Highway 101 through San Luis Obispo, California, the sign is difficult to miss. Bright pink with neon green lighting, it depicts a wagon pulled by a train of horses and points the way to what has been called by author Bel Mooney as the love child of Barbie and Fred Flintstone high on pink champagne and mead: The Madonna Inn. Described as kitschy, gaudy, over the top, or "like a wedding cake designed by someone who has just grasped the technique of making rosebuds and rosettes" the Madonna Inn is the antithesis of the typical roadside accommodation. ${ }^{1}$

With its emphasis on individuality and uniqueness, the Inn has become known worldwide. Travelers from other countries may not know where San Luis Obispo is, but when you mention the Madonna Inn, they often know exactly what you are talking about. The Inn is so popular that in order to reserve some of the rooms one must wait a year to book their accommodation. The notoriety it has received over the years begs the question of how this pink paragon of the delightfully absurd became popular to begin with. What was it about the Madonna Inn that initially attracted guests compared to the vast number of roadside inns available to travelers in the 1950s?

It is my assertion that the Madonna Inn stood at the center of three elements of history that combined together to create the perfect conditions for the Inn to thrive. First, the rise of the middle class in the 1950s provided more disposable income for people to engage in leisure activities such as travel. The

\footnotetext{
'Bel Mooney, "California Dream," The Guardian, May 22, 2004; Aljean Harmetz "California's Oddball Hotel," The New York Times, January 3, 1982.
} 
Madonna Inn provided a sort of elegance at an affordable price: the food was excellent, and accommodations elegant, yet they were reasonably priced, and the general ambiance was something most travelers had not seen in a typical inn. Second, the type of voyage that most Americans engaged in during the fifties was typically by automobile, which gave Alex Madonna and his Inn an opportunity to capitalize on this growing area of travel. Finally, the fifties Cold War climate filled Americans with a general fear of nuclear war as well as communist control of the world. The Madonna Inn allowed guests for a night or two to escape the anxiety that filled the American conscious and sub-conscious of the time.

The Madonna Inn fits into a historical trend of resorts that dates to the nineteenth century. The rise in middle-class income, the introduction of the steam engine, which provided cheap and reliable transportation to more remote locations, and the general fear of germs that caused unhealthy bodies in the $19^{\text {th }}$ century led to the popularity of resort cities like Bath and Brighton and resorts in the eastern United States that focused on wellness. The parallels between the two periods point to the fact that social, economic, political and scientific changes can influence the growth of particular travel establishments. With this we can see that the Madonna Inn is not in fact some strange anomaly, but rather an expected outcome of the time period in which it was built.

Travel throughout the world for the purpose of leisure is not a modern phenomenon. Because of this there are numerous books and articles that deal with the history of travel. Most of these works focus, like this work, on a specific 
resort or town where a resort is located. Some historians try to understand how hotels in general changed notions of class and race in a particular area over a long period of time. ${ }^{2}$

There are also those who study the economic transformations that led to travel throughout the centuries and how those economic changes caused certain areas of the world to become popular destinations of travel. Some historians look specifically at how the introduction of foreign goods into Europe influenced trade and travel and eventually found its way into the production of art, such as Vermeer's paintings. Other authors examine broad economic and social trends and how they transformed travel in Europe and throughout the world. The works of authors like Fernand Braudel were massive and thorough historical examinations that paved the way for closer inspections in areas of economics and social history. ${ }^{3}$

There is another form of historical work on travel that looks at the function of an inn throughout history; a macro-history on the subject of the inn. Some of these works chronicle the development of the English Inn from Roman times until the early twentieth century. Historians also look at the various uses of the Inn during different time periods and deal with the criminal element associated with the Inn during the sixteenth and seventeenth century. By comparison some

\footnotetext{
${ }^{2}$ Alice Garner, A Shifting Shore: Locals, Outsiders, and the Transformation of a French Fishing Town 1823-2000 (Ithaca, New York: Cornell University Press, 2005); A.K Sandoval-Strausz, Hotel: An American History (New Haven, Conn: Yale University Press, 2007).

${ }^{3}$ Timothy Brooks, Vermeer's Hat: The Seventeenth Century and the Dawn of the Global World, (London: Profile Books Ltd., 2009).; Wolfgang Schivelbusch, Taste of Paradise: A Social History of Spices, Stimulants and Intoxicants (New York: Vintage Books, 1992); Fernand Braudel, Wheels of Commerce (New York: Perennial Library, 1982); Richard Lachman, "Origins of the Capitalism in Western Europe: Economic and Political Aspects," Annual Review of Sociology 15 (1989):47; Richard S. Lambert, The Fortunate Traveler: A Short History of Touring and Travel for Pleasure (New York: Andrew Melrose Ltd, 1950).
} 
historians examine the Inn as a dining establishment and how food was slowly incorporated into the hospitality industry overtime. Some of these histories are impressive in their scope and time frame and deal not only with the relation of inns and drinking, but also look at the inception of medieval inns at monasteries. ${ }^{4}$

The historiography on the Madonna Inn is limited. There are a few senior projects at Cal Poly that deal with elements of the Madonna Inn. There are also newspapers and magazine articles that examine the Madonna Inn as a quirky vacation spot or look at Alex Madonna and the effect he had on local social issues. What is problematic about these sources is that they only offer a small glimpse of the entire story that is available to the historian. ${ }^{5}$

The largest work on the Madonna Inn, however, is written by the matriarch of the establishment, Phyllis Madonna. The advantage of this work is its firsthand knowledge of the inner workings of the establishment and of the thought process of the owner and developer, Alex Madonna. The negative aspect of the primary source is that the author does not provide an objective view of the history of both the man and the hotel, she also peppers her work with an element of sentimentality that is usually absent from most historical works. Her book reads more like a memoir than a history; however I believe that it was her objective to provide a memoir rather than a historical examination. ${ }^{6}$

\footnotetext{
${ }^{4}$ Denzil Batchelor, The English Inn (London: Batsford Ltd, 1963); Martha Carlin, "What Say You to a Piece of Beef and Mustard?: The Evolution of Public Dining in Medieval and Tudor London." The Huntington Library quarterly, (2008): 1-19; F.W. Hackwood, Inns, Ales and Drinking Customs of Old England (London: Bracken Books Publishing, 1909); Douglas Hay, Albion's Fatal Tree: Crime in $18^{\text {th }}$ century England, (London: A. Lane Publishing, 1975).

${ }^{5}$ Several of these articles are utilized within this paper, as will be shown later.

${ }^{6}$ Phyllis Madonna, Madonna Inn: My Point of View (San Luis Obispo: Pick and Shovel Publishing, 2002).
} 
What all of these works offer are indispensable historiographical examinations of the establishment of inns as a broader theme or the general history of travel from an economic or leisure viewpoint. Where they fail is the ability to look at how one particular inn fits into the broader historical narrative, which is what this paper is attempting to achieve. It is my aim to look at the forces of history that not only influenced travel during the time that the Madonna Inn was built (economic, social, political), but to connect the Madonna Inn with a broader history of resorts and the events that influenced their development in the nineteenth century. The aim of this thesis is to suggest that no structure or building is developed in a void, and the Madonna Inn is a product of historical forces. 


\section{The Madonna Inn}

Although it is probably the most widely known hotel on California's Central Coast, the Madonna Inn was not the first hotel or even motel in the area. The first establishment that could be considered a high-end hotel, compared to an establishment such as an inn which was typically someone's home with a restaurant attached, was the Ramona Hotel. On April 18, 1886 the Anderson Hotel, the primary hotel in San Luis Obispo, burned to the ground. To ensure that safety regulations for future hotels would be followed, San Luis Obispo businessmen formed the California Southern Hotel Company. With the introduction of the CSHC the economic focus of San Luis Obispo shifted toward travel and tourism. The CSHC was overseen by J. Millard Filmore, Charles Goodall, the Steeles, the Marres, Morris Goldtree, and R.E. Jack and the company developed the idea for a large retreat that would consist of 300 rooms and large spacious grounds which would allow plenty of room for the lavish establishment. After much debate over what to name the resort it was finally decided that it should be named the Ramona. ${ }^{7}$

Built in the 1880s and completed by 1888 with the anticipation of the completion of the railroad into San Luis Obispo, the hotel covered an entire block that is surrounded by Higuera, Johnson, Pepper, and Marsh streets. The fourstory wooden structure with 200 rooms and suites attracted local affluent residents as well as travelers from around the world with its multi-course meals and high tea in the afternoons. The Ramona boasted modern amenities such as hot and cold running water, gas and electric lights as well as an electric bell

\footnotetext{
${ }^{7}$ Carleton M. Winslow Jr. Discovering San Luis Obispo County (1971),61.
} 
service that summoned staff to guest rooms. All of this was available at a rate of $\$ 2$ to $\$ 3.50$ a $^{\text {night. }}{ }^{8}$ Unfortunately for the early San Luis Obispo residents who hoped to establish a high-end resort the hotel burned to the ground in 1905 and was never rebuilt. ${ }^{9}$

After the destruction of the Ramona Hotel the Glen Dell Hotel (later named the Hotel Park) opened which was more of a half-way house located in a threestory building at 1815 Osos Street. Constructed in 1910 near the Southern Pacific railway depot, it was built initially for railway employees, engineer James Reidy and his wife, and providing overnight accommodations for travelers. In 1920 the boarding house became the Axtell Hotel and by 1938 it was the Hotel Park. Today, after a $\$ 1$ million renovation, the hotel's upper levels are low-cost apartments and the bottom floors house retail establishments. ${ }^{10}$

Prior to the existence of these establishments there was the Hotel Marre, which was located in Port San Luis Obispo, commonly known today as Avila Beach. Before the completion of the railroad in 1901 the simplest and most costeffective means of travel was by steamships which stopped in Port San Luis Obispo. While awaiting transportation to take them inland to San Luis Obispo guests were able to stay in what was called the Ocean Hotel.

Built in 1876, when a steam railway was built between the wharf and San Luis Obispo, the Ocean Hotel catered to ships' guests that came into Port San

\footnotetext{
${ }^{8}$ By comparison one night stay at the Hotel del Coronado in San Diego, which was built the same year as the Ramona, cost between $\$ 3$ to $\$ 5$ during the months of April through October in 1892 . For a whole week the cost for two guests was $\$ 35$. Source: Hotel del Coronado Collection, Volume 203, Special Collections and University Archives, San Diego State University.

9 Janet Penn Franks, Images of America San Luis Obispo a History in Architecture (San

Francisco: Arcadia Publishing, 2004),109-110.

${ }^{10}$ Ibid., 116.
} 
Luis. However, a lack of funds forced the owners to sell the establishment to two Italian settlers, Luigi Marre and Mr. Gagliardo, and the hotel's name was changed to Hotel Marre. Like the Ramona this establishment burned down in 1934, however researchers believe that it probably fell out of favor once the steamships were no longer utilized by travelers long before the fire. ${ }^{11}$

Other than the Madonna Inn the most widely known motel on the Central Coast and one that claims to be the first "motel" in the world is the Motel Inn located in northern San Luis Obispo. The word motel actually stems from the term motor hotel which Carleton Winslow suggests was coined by the architect of the Motel Inn, Arthur Heineman in 1924.

Opening on December 12, 1924, the motel was designed in what is called "California Spanish Revival" and was sectioned off into little bungalows. The main building contained the front office as well as the dining room which had windows that faced both the highway and the courtyard where the bungalows were located. Each room had its own shower, bathtub, washbasin, toilet, and telephone which in 1924 were extremely modern for a road-side inn. The Motel Inn still exists today and was to be a purchase of King Ventures which owns boutique hotels within San Luis Obispo County. ${ }^{12}$

It was during this time of growth in San Luis Obispo County that Alex Madonna was born to the decedents of Swiss immigrants, Dora and Paul, on November 19, 1918. Madonna was the third child of the Madonna family and was raised in the rural area of just north of San Luis Obispo proper. The ranch

\footnotetext{
${ }^{11}$ Winslow, 103.

${ }^{12}$ Winslow, 55.
} 
where he was born and raised was located where Camp San Luis Obispo is today. Life for Madonna was not as lavish and abundant as it would later become; at the age of five his older brother Orville (the oldest of the three children) died of rheumatic fever and the family would lose its patriarch, Paul, in three years to pneumonia. This would force the family to move to apartments that were located close to Mission San Luis Obispo that had been purchased by Madonna's father prior to his death. ${ }^{13}$

As a young boy, Madonna would travel by horseback through the very hills that would later contain what many consider to be the most outlandish, gaudy and wonderful resort that California had ever seen. Initially this was not his intention. According to Alex's wife, Phyllis, what he wanted to create was a place where travelers could get good food and a place to rest that felt like home. What the Madonna Inn became was iconic. ${ }^{14}$

Alex Madonna initially made his fortune through youthful initiative and some financing from his mother. He borrowed $\$ 300$ to purchase a Model T Ford from his mother in high school and proceeded to contract himself out for odd jobs such as paving driveways with stone and pulling stranded drivers out of the dunes in Pismo for a fee. Madonna then rented a tractor from a local hardware store to place power poles on San Luis Obispo Mountain for PG\&E. While doing so Madonna rolled the tractor and not only broke his arm, but damaged the tractor forcing him to take out a $\$ 3200$ loan to purchase the vehicle. This

\footnotetext{
${ }_{13}^{13}$ Madonna, 13.

${ }^{14}$ Ibid.,90.
} 
contracted Madonna into a monthly payment of $\$ 126$ and this event would eventually change the course of his life. ${ }^{15}$

In order to pay off the loan Madonna opted not to attend college after graduation from San Luis Obispo High School and instead decided to start his own construction business. One of his first major jobs came about after he placed the lowest bid on the demolition of the county courthouse in San Luis Obispo and then sold the bricks of the building off one by one. His initial bid was roughly $\$ 400$ and he eventually made a profit of $\$ 1400$ from the project. "I figured if I went to work, I could make about four thousand dollars in four years... If I went to college, l'd go into debt that same amount. So... it seemed clear to me what I should spend the next four years doing." This was how Madonna rationalized his decision to forego college in order to start a business. ${ }^{16}$

After serving in the U.S. Army during World War II for the Army Corps of Engineers on the island of Okinawa, Madonna returned home to begin a road construction business and earned government contracts to build thoroughfares throughout California. Some of the projects that Madonna was known for were: Highway 166, most of Highway 101 between Salinas and Lompoc, the Concord bridge job, and the final stretch of Highway 5, which connected Canada, the United States and Mexico for which Madonna would receive the Golden Spike Award in 1977. It was during his travels throughout California fulfilling contracts for road construction that Madonna came up with the concept of the Inn. ${ }^{17}$

\footnotetext{
${ }^{15}$ Ibid.,18.

${ }^{16}$ Ibid., 17.

${ }^{17}$ lbid.,69, 78, 81, 83.
} 
While working on one of his highway jobs in 1949, Alex met the woman who would become his wife, his confidant and co-designer of the Madonna Inn, Phyllis. At the time of their first encounter Phyllis was working for the Union Oil Company in Orcutt. An accomplished baker (and accordion player) Phyllis had baked one of her co-workers a chocolate cake for a birthday celebration and was attending a luncheon at Elmer's Café. Alex just happened to be there as well having a lunch break while working on a project at Point Sal. He asked Phyllis out to dinner at Jacko's Steak House in Nipomo and the rest, as the proverb goes, is history. The couple wed just two months after their first date on December 28, 1949, in a small, stylish Las Vegas ceremony (the groom wore his only suit and the bride was given a twelve dollar wedding band) that had been secretly arranged by two friends. They would remain together until Alex's death in $2004 .^{18}$

Through the course of his building of roads throughout California, Madonna would stay in small local hotels and dine at nearby restaurants. He complained to his wife that, although they were adequate accommodations, these motor inns were not what a hotel should be. Phyllis stated that Alex informed her that after spending eighty percent of his time on the road that someday he would build a beautiful inn with an elegant dinning room and a pleasant coffee shop where weary travelers could feel at home and enjoy a nice meal, in a comfortable atmosphere and continue on their journey. ${ }^{19}$

\footnotetext{
${ }^{18}$ lbid.,41.

${ }^{19}$ Ibid.,91.
} 
Upon the announcement that he would venture into a new business Phyllis did not hesitate to support her husband or even caution him on the danger of venturing into an area of business that can bankrupt even the most savvy business man. She stated, she never questioned any of her husband's decisions because she had total trust and faith in him and whatever he chose to do. Madonna himself had reservations about the project initially for fear of taking away business from other hotels in the area which were owned by acquaintances. $^{20}$

When San Luis Obispo held a government auction of surplus land in 1957 initially Madonna said he was not interested. However, his secretary knew her employer better and bid $\$ 18,000$ of the $\$ 20,000$ that the city was asking for the property. The land was conveniently located between French Road, which would later become Madonna Road, and Highway 101. The first bid was rejected and the property was placed up for auction two more times before Madonna decided that the land would be appropriate for his new venture. At this point another bidder had forced the price of the property up until Madonna paid $\$ 25,000 .{ }^{21}$

Initially there were only twelve rooms constructed on the property of which had a different design. Madonna stated the reason for the different interiors of each room was that it was an opportunity to make "more people happy." Phyllis stated that when it came to the design of the rooms while she and Alex looked at wallpaper patterns and swatches of fabric for the furniture they felt overwhelmed by the task, so they decided to hire an interior designer for the project. Phyllis

\footnotetext{
${ }^{20}$ Phyllis Madonna, e-mail message sent to author, May,5 2011.

${ }^{21}$ John Brennan, "Madonna: The Man and the Inn" (Senior Project, California Polytechnic University of San Luis Obispo, 1971),10-11.
} 
would eventually become so adept at her design skills that in 1960 she entered and won the Winter Wonderland Show where she submitted a room called the " $50^{\text {th }}$ State Room" featuring a Hawaiian theme. Phyllis said she never thought she would take first prize and only entered because Alex asked her to. ${ }^{22}$

After the initial consultation with the interior designers the Madonnas realized that the very patterns that he and Phyllis favored were the designs that the experts suggested. With that Alex, decided that they could save money and informed his wife that she would be in charge of the interior design. She stated that she did not want her husband to know just how overwhelming this task seemed so she agreed to do it for him. Today with expansion there are 110 rooms with various themes to each.

Upon the opening of the Madonna Inn on Christmas Eve 1958 the rates ranged from $\$ 7$ to $\$ 20$ for each room depending upon how many adult guests were to stay in the accommodations. ${ }^{23}$ Sally O'Day, the only employee at the time, called Madonna that evening to inform him that the hotel had its first customers, the Spreitzer family. Upon hearing that the first guests had checked in Alex, Phyllis and their family went down to thank the Spreitzers and waived the seven dollar room fee. Since that day the Inn has been open year round. ${ }^{24}$

The only exception to the year-round visual frivolity that the Madonna Inn supplies its guests occurred in 1962 when the twelve original, of the forty existing rooms, burned to the ground. At 2am on May 2, an employee at the coffee shop

\footnotetext{
${ }^{22}$ Madonna,135.

${ }^{23}$ By comparison one night stay at the West Shore Manor in Oregon was $\$ 18$ which included two meals. Audrey Withers ed. "Eight Attractive Places to Eat and Sleep in United States Coast to Coast" Vogue (August 1960).

${ }^{24}$ Ibid.,92, 97.
} 
noticed that flames were coming out of one of the hotel rooms at the Inn. Not only did he call San Luis Obispo fire department, but he also called Alex Madonna who rushed to the scene to help extinguish the blaze. According to the local fire department what complicated the matter was the fact that the closest fire hydrant was almost a mile down the road. Although the fire trucks themselves had water by the time they began attacking the blaze they had almost exhausted their resources. The fire crew was then forced to attach their hoses to a three inch standpipe at the front of the main building some two hundred yards away from the fire. By $4 a m$ when the fire was finally put out it had caused over $\$ 200,000$ worth of damage and forced the closure of a portion of the $\operatorname{Inn} .^{25}$

The Copper Coffee Shop was built, completed, and opened by 1960 after the construction of the Wine Cellar had been completed for a Centennial dinner. The large dining room and the banquet hall were finished in a few days in 1962 and opening night of September $4^{\text {th }}$, the Gold Rush Steak House served two hundred meals that Alex had cooked himself. Madonna acquired a marble balustrade from the Hearst Family that now stands in the lobby of the Madonna Inn and the very large tree light fixture in the Gold Rush Steak House Dining room was made from left over conduit and wiring that had been used throughout the building. ${ }^{26}$ \{See Images F2 and F3\}

The Inn itself is clearly influenced by not only Phyllis' eye for the elaborate, but the Swiss heritage can also be seen in much of the woodwork throughout the

\footnotetext{
${ }^{25}$ Ibid., 152.

${ }^{26}$ Brennen, 14-15.
} 
main building. This Swiss chalet influence ${ }^{27}$ can also be seen through the use of numerous boulders throughout the structures. Two sources that supplied boulders, if they were not already present upon the beginning of construction, were San Luis Obispo Mountain and Adelaide. The two hundred ton boulders from the mountain would be rolled down in a zigzag fashion by bulldozer which reduced the speed and where the boulders landed would determine where particular buildings would exist. ${ }^{28}\{$ See Images F4 and F5\}

The intricate woodwork was all done by one particular craftsman, Alexander Zeller, nicknamed "Mr. Chips" during his service for the American Army in World War II. The fifty-two year old Munich born artist was hired by Madonna in 1961 to carve the detailed lattice work and pillars throughout the main building. Zeller moved to San Luis Obispo from San Juan Bautista, where he was renowned for his sculptures, to work exclusively for Madonna and stayed in the area for well over half a year until his portion of the project was completed. Madonna also commissioned the work of artist Alice Williams, who had worked for Walt Disney, to paint the wall in the Old Mill Room at the Inn. ${ }^{29}$ \{See Image F6 $\}$ In the initial years the cakes and pies that the Madonna Inn is now famous for were baked by Phyllis herself. On average she would bake anywhere from ten to twenty pies a day for the coffee shop and typically they were her now famous cheese pies which consisted of cream cheese mixed with lemon zest and other ingredients. Some of their most popular cakes today include the Black Forest

\footnotetext{
${ }^{27}$ The Swiss influenced of the Inn was Phyllis and Alex's own interpretation of Swiss Chalet design. Eventually the two would travel to Europe, but this did not directly affect the interior design of the Inn itself. Clint Pearce, e-mail sent to author, November 11, 2011.

${ }^{28}$ Madonna, 105.

${ }^{29}$ Ibid., 110, 278.
} 
Cake and the Pink Champagne each standing almost a foot in height and adorned with dark chocolate and pink chocolate swirls respectively. ${ }^{30}$ \{See Image F7\}

Pink is abundant throughout the building. When asked about the color both Madonna and his wife stated that it was one of the most difficult questions about the Inn to answer. They both liked the "wonderful rich color" and both felt that they wanted a color that "flattered people and made them feel relaxed and happy when they were around it. We feel pink spotlights people and highlights their positive attributes." ${ }^{31}$ The shade of pink they used became so synonymous with the Inn that today one can go to a designer show and find the same color labeled "Madonna Pink." The Inn even has its very own manufactured pink sugar for the coffee shop.

Most who visit the Inn display a mixed response that range from awe to disgust. For some there are no words within the human language that can be used to describe the Madonna Inn;

Let's say that Albert Speer, while leafing through a book on Gaudi, swallowed an overgenerous dose of LSD and began to build a nuptial catacomb for Liza Minnelli. But that doesn't give you an idea. $^{32}$

For some the Madonna in defies common sense when it comes to how items should blend for an aesthetically pleasing design.

In addition to the pink that some refer to as kitschy, gaudy, and over the top each of the rooms has themes that vary which was Alex's plan to keep his

\footnotetext{
${ }^{30}$ Ibid., 126

31 lbid., 245.

32 Umberto Eco Travels in Hyper-Reality, (Orlando Florida: Harcourt Inc, 1986), 24.
} 
guests entertained and happy. In her article in Essence magazine called "Adventures for Two" Nicole Alper describes the accommodations that allow guests to have a unique romantic getaway, "At the Madonna Inn (madonnainn.com), you can choose from 109 completely remarkable rooms, from the all-pink Love Nest $(\$ 246)$ to the red leather walls of the Tack Room (\$223). Pack your best animal skin and check in to a favorite, the Caveman Room (\$246), which has rock floors, walls and ceiling. You can even relax together under a waterfall rock shower." 33

Most of the rooms at the Inn were not an easy feat to construct and as mentioned previously had dimensions that were determined by the placement of very large boulders throughout the ten acres that the Inn resides on. The Caveman Room, which is probably the most popular and widely recognized room at the Inn, took six hours to put the rock together to form the room itself. The walls, ceilings and floors are all lined with flagstone and boulders which were all set to stand by themselves and mortared just to make them more secure. The ceiling of the Caveman room is cantilevered (as are all the rock rooms) to make the room more structurally sound. The Caveman Room also features the rock waterfall shower; solid rock basin sinks as well as custom stained glass windows which are featured throughout the $\operatorname{lnn} .^{34}$

The Bridal Falls Suite, which also contains a waterfall shower, was designed specifically around the furniture that was placed in the room. While designing the Old World Room Phyllis insisted that the workmen keep the back

\footnotetext{
${ }^{33}$ Nicole Alper, "Adventures for Two," Essence (Time Inc.), 38 Issue 3, July 2007,168.

${ }^{34}$ Madonna, 259.
} 
of a fireplace open so that a large wooden desk could be moved through to the adjoining suite. The Cabin Still Room is another room that has a customized element; a sink that contains a copper replica of an old-fashioned still that would have been used for moonshining. With the Old Fashion Honeymoon room Phyllis involved herself by helping the construction workers with the band saw to complete the wooden grillwork in the room which today is a source of great pride for her. It was with this, and many other design aspects of the Inn, that Phyllis was given the title of "determined" by her husband. ${ }^{35}$

That label is best displayed in a surprise birthday gift that Phyllis presented to Alex one year. Phyllis took a space that was originally a storage room for paint supplies and transformed it into a Western themed room that could be privately used by Alex as a "place where he could get away if needed, for a quiet time alone." Utilizing an old buckboard wagon found on the property which had solid oak wheels, Phyllis created a king sized bed complete with reupholstered buckboard seat and sand blasted metal as well as brass plating. Curtains in the room were made of blue denim and the carpet featured a bandana pattern. The personal touch was added to the room by placing pictures of Madonna's children and grandchildren. This room is not open to the public and is only used on special occasions. ${ }^{36}$

Because of the various materials utilized in each of the rooms, cleaning is a meticulous and painstaking process which can involve various types of cleaners in order to maintain the beauty of the unique fixtures in the rooms. One

\footnotetext{
${ }^{35}$ Ibid., 262, 275, 277.

${ }^{36}$ Ibid., 282.
} 
cannot use the same cleaner for a porcelain washbasin as one would for a rock or brass washbasin. Not only are the materials in the room unique, but the size and scope of the cleaning task of the housekeeping staff is monumental. In the Austrian Suite there is seventy-two feet of carpet that must be vacuumed between each guest's stay. Each rock bathroom floor is scrubbed by hand using a brush and the rock wash basins are cleaned with toothbrushes to remove dirt from the crevices. To prevent monotony on the job, and wear and tear on the knees, the housekeepers are on a rotating room schedule which means they are faced with a different cleaning challenge every shift. ${ }^{37}$

The rooms themselves are not the only attraction for visitors who travel to the Central Coast. As mentioned by Gene Sloan, Kitty Bean Yancey and Jennifer Vishnevsky in their article "Sit Down and Stay a While in These Stylish Restrooms" the waterfall urinal in the men's bathroom is a favorite attraction for travelers. According to Phyllis this, other than the fire, was one of the greatest difficulties that confronted Madonna during construction. The initial drawing for the bathroom was done on a napkin and when Madonna presented it to the county planners they all argued that a waterfall urinal could not be done properly. Phyllis states that she believes that even today the urinal in the men's room is one of the main reasons that people travel from around the world to visit the Inn. ${ }^{38}$ \{See Images F8, F9, F10, and F11\}

\footnotetext{
${ }^{37}$ Doug Parker, "On Spic-and-Span Patrol at the Madonna Inn," Telegram Tribune, July 20,1985. ${ }^{38}$ Gene Sloan, Kitty Bean Yancey, and Jennifer Vishnevsky. "Sit Down and Stay a While in These Stylish Restrooms," USA Today, April 2005. Phyllis Madonna, e-mail message to author, May 5, 2011.
} 
It was a distinctive interior design by Alex and Phyllis Madonna that would eventually attract not only the everyday traveler, but the famous as well. The banquet functions as well as the fundraisers that Alex and Phyllis hosted attracted the likes of Raymond Burr, Barbara Streisand, Paul Newman and Joan Woodward, Tennessee Ernie Ford and Robert Mitchum just to name a few. ${ }^{39}$

While some establishments attempt to increase their "ambiance" in relation to the type of guests they receive, Phyllis stated that despite the famous clientele the Madonna Inn always tried to retain a down home feeling. When asked how that was done she responded that it was through the food that they served, "I feel that any of the well known people that visit us come because of our friendliness and down home cooking. We strive to make our food exactly like you would make in your own kitchen. We haven't changed for the celebrities because they all seem to like us just the way we are." She also mentioned that the colors of the Inn created an atmosphere that was warm and welcoming like someone's home. ${ }^{40}$

Not only because of his name, but also because of his cattle business which included the 2,200 acre parcel that the Inn resides upon, Madonna established a personal and professional relationship with John Wayne. Along with Louie Johnson, Madonna and Wayne established the Red River Feed Lot in Stanfield Arizona where thousands of cattle were fed and raised. In addition to the feed lot Wayne partnered with Madonna in the mining of a product called " 76 "

\footnotetext{
${ }^{39}$ Madonna, 127.

${ }^{40}$ Phyllis Madonna, e-mail message to author, May 5, 2011.
} 
which was extracted from Angels Camp California. It was a natural binding material that was used to strengthen cement and general building materials. ${ }^{41}$

Christmas at the Madonna Inn is a tradition that attracts locals and visitors alike. The entire main building is covered in Christmas lights as well as large and small animals and animated figures that swing from the rafters of the lobby. An average of eighty to one hundred Christmas trees fills the entire Gold Rush Dining Room. Phyllis enjoys changing the decorations in the Dining Room based upon the seasons, but her favorite holidays to decorate are Valentine's Day, Easter, Thanksgiving and Christmas. ${ }^{42}$

The attention the Inn received has led to it garnering a series of awards and acclaim locally as well as statewide and internationally. In April of 1971 Madonna was awarded for his contribution to the local economy by the President of Cal Poly San Luis Obispo Robert E. Kennedy, State Senator Donald Grunsky and Assemblyman William Ketchum. However, critics of Madonna might suggest that it was his association with highway construction and garnering of government contracts that placed him in good favor with the politicians at that time.

Unfortunately, Alex Madonna was not able to realize all of his hopes and dreams for the Inn. In 2004 Madonna passed away from a suspected heart attack at his home at the age of 85 . His funeral procession was indicative of the man. His family wore pink in remembrance of his work, his casket was embossed with the pick and shovel pink emblem of his construction company as well and

\footnotetext{
${ }^{41}$ Madonna, 191.

${ }^{42}$ Ibid., 323.
} 
his casket was placed in a horse drawn carriage that was pulled through town as residents lined the streets to give a final farewell.

Both Alex and Phyllis were devout Catholics and because of this the funeral was held in the San Luis Obispo Mission just adjacent to where the apartment complex was located that had housed Madonna's family after his father's death. After Phyllis spoke to the over-crowded church of mourners thanking them for their outpouring of kindness, the congregation clapped and some yelled out "yahoo" which was a call that Madonna himself made on several trail rides. ${ }^{43}$

When Alex Madonna passed away he still had further plans that he had hoped to finish at the Inn. After purchasing the mountain just adjacent to his property in 1973 (which is now dubbed Madonna Mountain) Alex spoke of building a wedding chapel on the property from the remains of a fourteenth century barn that had belonged to the Hearst family. ${ }^{44}$ This idea was then transformed into an entire Alpine Village which would include a parking lot, a tourist center and two office complexes at an elevation of three-hundred and twenty feet. Madonna also proposed cutting off the top of the peak to place a restaurant at that location, but was denied by the city planners. ${ }^{45}$

Madonna also wanted to build a larger event center which was later completed by his wife and daughter who is the current general manager of the

\footnotetext{
${ }^{43}$ Julie Lynem and Carol Roberts, "True Original; Thousands Turn Out to Pay Tribute to One of the Most Influential and Charismatic Personalities San Luis Obispo County has Ever Known," Telegram Tribune, April 30, 2004.

${ }^{44}$ The family still owns this barn which they have plans for yet to be disclosed to the public. Clint Pearce, e-mail sent to author, November 11, 2011.

${ }^{45}$ Alan Mittelstaedt, "Bold Madonna Plan; Alpine Village Envisioned on Peak," Telegram Tribune (no date).
} 
Madonna Inn. The Madonna Expo Center was completed in 2005 and is used today for the yearly fashion show that Phyllis oversees to raise money for the Women's Shelter of San Luis Obispo. One aspect of the Inn that Madonna had not planned for, and was constructed after his death, was the pool and spa that is now located adjacent to the hotel. Rumor abounded throughout the county that the plans for the pool included a clothing or nude option very similar to what one would find at a European resort. Construction of the pool project began around the same time the Madonna Expo Center was completed in 2007.

Today the Inn boasts a staff of over two-hundred and visitors are forced to wait up to a year for a particular room when they book their accommodations. The general manager of the Inn is Alex Madonna's daughter Connie ${ }^{46}$ and each of the four Madonna children, along with their spouses, are involved in the day to day maintenance of the Inn as well as Madonna's flourishing cattle ranch. Glenda Warre ${ }^{47}$ stated that regardless of what people thought about the Inn or what their interpretation was of the décor she felt that Alex Madonna simply did what he wanted to do. He loved pink and wanted to wash his entire establishment in it despite what people may think of the color. When one examines the Inn through this perspective it would be easy to relate Alex Madonna to the Folk Art movement or the Outsider Art Movement of the United States during the 1950s.

\footnotetext{
${ }^{46}$ Connie Pearce has been General Manager of the Madonna Inn since 1998. Clint Pearce, email sent to author, November 11, 2011.

${ }^{47}$ Glenda Warren is a seventh generation San Luis Obispo native whose family property, acquired through a Spanish land grant, was directly adjacent to the Madonna family property on Highway 1. In addition, Mrs. Warren's husband worked for Alex Madonna applying plaster to the ceilings inside the main building of the Inn.Glenda Warren, interview conducted on October 10, 2011.
} 
The roots of the Outsider Art movement can be seen in works of artists in Europe in the early $20^{\text {th }}$ century, but the actual notion of works that did not fit the parameters of the art world began in France in the 1950s. Artist Jean Dubuffet coined the phrase "art brut" based upon the art he collected from mental patients in French asylums and self taught artists. ${ }^{48}$

This notion of the "outsider" creating masterpieces was later acknowledged in the United States through artists such as Howard Finster. For the "outsider" artists their vision of what is aesthetically pleasing is not inspired by what they see around them, rather they driven by passion, extreme ideology, a sense of marginalization from the rest of society or desperate need to be heard and seen by the art world. ${ }^{49}$

In the 1960 s roadside hotels were priding themselves on the fact that one could stay in the exact same room in New York City as one could in Los Angeles. During a time period when most hotels, such as Howard Johnsons, were favoring a design that bred a sense a familiarity and comfort in "sameness" Madonna deviated from the norm and designed a hotel where one could experience something different each time they visited. It is because of this desire to deviate from what was "normal" that one could suggest that Alex Madonna was a sort of folk artist or outsider.

When looking at interior design it is not just a question of what is pleasing to the eye, but it is also an issue of functionality of the design. German Bauhaus

\footnotetext{
${ }^{48}$ Michael D. Hall, and Eugene W. Metcalf Jr. ed. The Artist Outsider: Creativity and the Boundaries of Culture. (Washington D.C: Smithsonian Institution Press, 1994), xiii.

${ }^{49}$ Greg Bottoms, The Colorful Apocalypse: Journeys in Outsider Art.( Chicago, Illinois: University of Chicago Press, 2007), 9.
} 
design of the 1920s may indeed have been pleasing to the artist sensibility, but would the "cool elegance" be viewed by the everyday person as cold and sterile? So when examining the Madonna Inn it is not just a question of whether or not it is fascinating to look at but what function does it have within society? What the Madonna Inn provided was a very basic human need to have our surroundings adorned with decorative elements to relieve monotony. ${ }^{50}$

Whether Alex Madonna saw himself as an artist is debatable, however not all outsider artists or "primitives" as they are sometimes referred to necessarily see themselves as skirting the fringes of the art world. Rather the folk artist, the outsider, the primitive or the self-taught artist follows their passion for what they find to be pleasing to their own sensibility. They have a "raw vision" that has been untainted by the "sinful fruits of the art-world knowledge."

Despite what one personally feels about the look and feel of the Madonna Inn it can not be denied that the Inn contributed greatly to recognition of the city of San Luis Obispo when it was opened in the 1950s and continues to do so today. This examination will now turn its focus to the three pivotal forces in history that made the Madonna Inn possible; technological advances in roads and automobile travel, fear of nuclear war with the Soviet Union, and the economic improvements for middle class Americans. It will be shown that these

\footnotetext{
${ }^{50}$ Victor Papanek, "The Function of Beauty" in Beauty is Nowhere: Ethical Issues in Art and Design, ed. Richard Roth and Susan King Roth ( Amsterdam, Netherlands: G\&B Arts International, 1998), 40-41.

51 Joanne Cubbs, "Rebels Mystics and Outcasts: The Romantic Artist Outsider." in The Artist Outsider: Creativity and the Boundaries of Culture, ed. Michael D. Hall and Eugene W. Metcalf Jr. (Washington D.C.: Smithsonian Institution Press, 1994), 88.
} 
three themes (transportation technology, fear, and economic prosperity) were also present at the time that resorts rose to prosperity in the nineteenth century. 


\section{Travel Technology}

In 1861 travel through California was becoming more efficient with the stagecoach which brought much business as well as development to San Luis Obispo. By 1873 the Southern Pacific Railroad established a line as far south as Salinas with the stagecoach traveling the remainder to San Luis Obispo. It would not be until 1894 that the railroad would be finished through to San Luis over the Cuesta Grade. The large percentage of development in San Luis Obispo County stems from the building of the railroad and then later the construction of highways such as 101 and 1 . Because of its location and relation to the four other counties in District V of California, San Luis Obispo would be chosen as the district headquarters for the California Highway Commission in 1912 which would have profound effect on the travel industry of San Luis Obispo. ${ }^{52}$

Seven years after the establishment of San Luis Obispo as the district headquarters and a year before William Randolf Hearst began his "castle" in the hills of San Simeon, Alex Madonna would be born on a ranch located off of Highway One. He would build his "Home away from Home" hotel adjacent to would become Highway 101 and road construction as well as travel would become a central theme to Madonna's life. When one examines the life of Alex Madonna we discover that Madonna was instrumental in the development of the city itself through the construction of the roads that would bring tourists to his dream Inn.

Similar to the small town of San Luis Obispo, what helped to change the dimensions of the French town of Arcachon was the introduction of the railway in

\footnotetext{
${ }^{52}$ Winslow,31,34.
} 
the mid-nineteenth century. Very much like other remote towns, which were only frequented by the wealthy who could afford comfortable travel there, the introduction of the steam engine and railroad allowed for families of lower incomes to travel to wellness resorts in a comfortable inexpensive fashion. ${ }^{53}$

With improvements in transportation remotes spas such as the one in Saratoga Springs experienced an increased level of success during the nineteenth century. When steamboats were allowed on the Hudson and a rail way line was completed between Schenectady to Ballston, which provided an inexpensive way to travel to the resort, people from various social classes were able to frequent the spa. Like Saratoga Springs the little French seaside town of Arcachon went from a health resort for the wealthy to a popular destination for all classes; the completion of the railway to the town was a major factor in the increased number of visitors. ${ }^{54}$

The development of the steam engine in the nineteenth century not only contributed to increased accessibility to remote locations throughout Europe and the United States, but it also provided an affordable means of transportation for poorer and middle income classes of people. Because of a reduction in the price of travel the middle class was capable of traveling longer distances for vacation purposes rather than for business as had typically been the case in the past.

It was with the completion of Highway 101 that San Luis Obispo began its transformation from a rural town to the vacation destination that is now today. Even though the introduction of automobile travel decreased the use of train

\footnotetext{
${ }^{53}$ Garner,86.

${ }^{54}$ Thomas Weiss, "Tourism in America before World War II," The Journal of Economic History 64, No. 2 (Jun. 2004): 296.
} 
travel, by 1925 the Union Pacific Railway was still a very instrumental part of San Luis Obispo's structural layout. Many of the streets of San Luis Obispo run diagonally, instead of east to west or north to south, based upon their relation to the train tracks and station.

Despite the central role that the railroad played in the development of the city, by the 1930s it was clear that there was a tourist element in the city that was introduced by automobile. Seventy-five per cent of the hotel business of the city was tourist business, less than ten per cent of that travel came by train to the city. Although most of the tourist traffic exists during the summer months, there is travel business all year round in San Luis Obispo because it is considered a stop-over location. It is clear that a portion of the growth in San Luis Obispo was due to its convenient location half-way between San Francisco and Los Angeles. ${ }^{55}$

It would be road construction like that of Highway 101 that would afford Madonna the opportunity and income to build his dream Inn. Road contracts supplied to him by the state and federal government in the 1950s and 1960 s supplied Madonna the income needed to begin building the Inn. Madonna, his Inn, and road travel would become so inextricably intertwined that at one point the Madonna Inn contained a Union 76 gas station in order to encourage road travelers to find all of their basic necessities in one place. Union Seventy Six Oil Company actually featured the Madonna Inn in a company magazine that it published every two months.

55 John Wesley Coulter, "San Luis Obispo" Economic Geography 7, No. 3 (Jul., 1931): 315. 
In its exposé the company extols the amazing sights at the Inn like the men's bathroom, but is quick to point out that the Inn is more than a typical motel, "The Inn- it's composed of several buildings-is cradled by the soft-rolling San Luis Obispo mountains and it extends it wings southward to embrace a stone fortified Union 76 station-modified a la Madonna." 56 The mere fact that Union 76 Oil Company would write an article about the Inn suggests just how intertwined the Inn, Madonna, and the business of freeway expansion really were. \{See Images F12 and F 13\}

Dwight $\mathrm{D}$. Eisenhower during his presidency made a point to fund the construction and maintenance of the blooming freeway system in America. Although public works programs that helped build freeways had existed during the Depression it was not until the 1950s that the government began to focus on the highway system as a source of revenue for communities. Post-war Acts of Congress that allowed service-men to move to the suburbs highlighted the need for functioning paved roads to encourage visits to the cities in their shinny new cars that they also purchased through their surplus income. Although the initial purpose for the road construction acts was not highway travel the unexpected result was an increase in cross country travel. ${ }^{57}$

By the time Eisenhower took office unsafe roads caused thirty-six thousand fatalities and more than one million injuries annually. Not only were the economy of cities and safety of motorists major determining factors for building

\footnotetext{
${ }^{56}$ Peter Craigmoe ed. "Alex Madonna: Innkeeper Extraordinary," Seventy Six Union Oil Company of California, (May/June 1970),11.

${ }^{57}$ Chester J. Pach Jr. and Elmo Richardson, The Presidency of Dwight D. Eisenhower, (Lawrence Kansas: University of Kansas Press, 1991), 123.
} 
and paving roads during the time period, but fears of nuclear destruction of cities also encouraged the government to build roads that made it possible for mass evacuation if necessary. Although Madonna began his road construction company prior to the National Interstate and Defense Highway Act of 1956, he clearly would benefit later from government promotion of the highway system. ${ }^{58}$

The 1944 Federal-Aid Highway Act provided 1.5 billion dollars in road building funds in three years half of which was dedicated to primary routes such as main streets and freeways. However, those numbers increased dramatically from 1954, during the Eisenhower administration, up until the Johnson administration in 1969. Money was allocated for primary work, secondary work, urban and interstate and in 1954 all four sections totaled just above five hundred million dollars. By 1969 that amount increased to just above 4.5 billion dollars, 3.5 of which were allocated for interstate construction. Because of all this spending it was necessary for towns and cities to dedicate funds that would assist with planning to incorporate these new freeways into their infrastructure. ${ }^{59}$

Eisenhower saw the construction and improvement of the U.S. highways system as a major issue for his administration for reasons other than just maintenance. For Eisenhower he saw the potential passing of the Highways Act as a positive political move for the Republican Party. However, he stated that his main aim was to help improve conditions on the U.S. roadways which, upon his

\footnotetext{
${ }^{58}$ It should be noted that as of 2004 the United States death toll due to road accidents was still in the tens of thousands and that road conditions had greatly improved at that time compared to the 1940s. Source: Committee on Transportation and Infrastructure, "Celebrating 50 Years: The Eisenhower Interstate Highway System," (United States Printing Office 2004), 19; Robert L. Branyan and Lawrence H. Larsen, The Eisenhower Administration 1953-1961 a Documentary History, (New York, New York: Random House, 1971), 545.

${ }^{59}$ Owen D. Gutfreund, $20^{\text {th }}$ Century Sprawl: Highways and the Reshaping of the American Landscape, (New York, New York: Oxford University Press, 2004), 46-47.
} 
return from Europe in 1945, he saw as being in "shocking condition." Eisenhower believed that more cars and safe roads would help to improve the morale of the American people and increase the standard of living. ${ }^{60}$

Freeways, for the Eisenhower administration, were so vital to the American way of life that on February 22, 1955 Eisenhower gave a special message to Congress regarding the National Highway Program which stressed that the unity of the nation was sustained by free communication of thought and easy transport of people and goods throughout the country. For Eisenhower the individual and commercial movement was only made possible through the interconnected highway system which also facilitated friendly relations with nations to the north and the south of the United States. Eisenhower made a strong argument that the freeway system, which was in desperate need of repair, represented more than just a way of navigating the United States; these highways represented a united post-World War II nation rebuilding itself. ${ }^{61}$

The issue of city planning in Southern Californian cities with tourism strictly in mind is referred to as "infrastructure of sights." This notion addresses the belief that businessmen, like Madonna, organize their establishments (whether it be a hotel or an amusement park) adjacent to large roadways in order to monopolize on accessibility. Madonna having a background in road construction surely knew the importance of visibility from a freeway even if that freeway was not yet paved when he started construction on his establishment.

\footnotetext{
${ }^{60}$ Pach, 123.

${ }^{61}$ Branyan, 544.
} 
The U.S. Government, in order to boost the rising economic benefit from tourism, would extend government grants to improve the roads that lay adjacent to establishments similar to Madonna's hotel. The layout of the freeways in Southern California played a crucial role in relation to the development of Disneyland in Anaheim. It is interesting to note that Disneyland was completed a mere three years before the completion of the Madonna Inn. It could be argued that in some way subconsciously or not Madonna was taking a page out of Disney's book; different lands for different tastes in fantasy. ${ }^{62}$

As briefly mentioned earlier, highways played a major role in the establishment of the American culture. In order to contrast itself with its Cold War counterpart, the U.S.S.R., the United States culture had to establish itself as a nation of individuals. Freedom to travel the large nation, freedom of choice, and expression of their individuality could be displayed by staying in a hotel that offered various rooms designed to cater to their particular taste like the Madonna Inn. In addition, the Eisenhower administration had to create an image of a utopian society even if it did not exist. ${ }^{63}$

Along with the comfy atmosphere of these newer larger automobiles of the 1950s, some historians argue that the very design of the freeway system of the time encouraged Americans to drive and to discover that driving was not a monotonous experience, but rather could be pleasurable in and of itself...

\footnotetext{
62 Susan Davis, "Tourism in Southern California," Pacific Historical Review 68, No. 2, Orange Empires (May, 1999): 173-178.

${ }^{63}$ Philip Abbot, "Eisenhower, King Utopus, and the Fifties Decade in America," Presidential Studies Quarterly, (March 2002): 8.
} 
"freeway driving offers excitement, adventure, freedom, and can give us a unique perception of the landscape." ${ }^{.64}$

The road symbolizes something within the American culture, an American ideal of freedom: freedom of choice on how one would navigate the road, freedom of where one could travel and freedom to choose what type of establishment to stay in while "on the road." Particular establishments were developed specifically for the automobile such as drive-in movies, fast-food restaurants, scenic drives, camp-sites, "recreational" vehicles, and finally our point of interest hotels. ${ }^{65}$

An alternate view of travel can be seen in a trend in the fifties where the road traveler was referred to as the "mechanized tourist"; people who had fallen victim to "Industrial Tourism". Industrial tourism suggests that tourism is a commodity to be sold for mass consumption. Some historians saw tourists as victims of motels, the oil companies, and the automotive industry. These authors also suggest that a major culprit of this marketing venture were the states themselves. State and federal governments were responsible for granting land for the allowance of highway construction which would facilitate the growth of the tourism industry. The infrastructure of specific states was designed solely around the burgeoning tourism industry. ${ }^{66}$

State sponsored tourism, which is a case when states pour funds into private businesses that promote tourism such as Automobile Association of

\footnotetext{
${ }^{64}$ Vivien Arnold, "The Image of the Freeway" JAE, 30, No. 1, Teaching the Landscape, (September, 1976): 28.

65 Ibid., 28-29.

${ }^{66}$ Susan Sessions Rough, "Branding Utah: Industrial Tourism in the Postwar American West" The Western Historical Quarterly 37, No. 4 (Winter, 2006): 446.
} 
America and local chambers of commerce, transformed the western United States. Pre-war West was an area which had an economy based upon the export of raw materials for the war effort, but post war West transformed its economic structure to focus on the growth of tourism as a major commodity.

The same could be argued for the Central Coast of California and specifically San Luis Obispo. Prior to the construction of Highway 101 the hub of the Central Coast had been north of San Luis Obispo in Paso Robles where the train lines ended. With the construction and paving of Highway 101 San Luis Obispo became a more marketable town as a tourist destination. Here we see just how complicated a role Alex Madonna takes in the history of San Luis Obispo and its growth. Not only was he in charge of one of the largest construction companies in California that won several bids for the building of highways in the State, but he was also a hotel proprietor who had influence on how accessible his hotel could be to the road traveler of the fifties.

States create an image of themselves that can be packaged and sold to the traveler abroad. California, since the Depression of the 1930s, has been portrayed as the Golden State filled with possibilities; if one can dream it, in all likelihood it exists in California. California, therefore, had become synonymous with fantasies becoming reality. Utah created an image in the 1950s to counter the representation of a separatist and closed-minded society that had been linked with it for centuries because of the Mormon Church. By contrast it depicted itself as an open and friendly state that would welcome people from all across the 
United States. This slogan would later be changed to the land of Color to promote the dramatic landscape one would see in Utah. ${ }^{67}$

In some instances tourist and publicity councils, such as the one in Utah, were combined with entities like the State Road Commission in order to obtain proper funding for advertisements. A specific person within the Council would then be responsible for writing articles for magazines such as Better Homes and Gardens which would tout the easy accessibility by car to all of the wonders of that specific state. ${ }^{68}$

The maintenance and development of specific highways became incredibly important to the development and continued growth within specific communities. U.S. Highway 16 in South Dakota is a prime example of how one road can change the face of a community due to a new tourist economy. Like San Luis Obispo County, most of the growth in the Badlands region of South Dakota revolved around the railroads prior to the construction of U.S. Highway 16. Most of the roads in the region were dirt and simply connected one small town with another, but the general layout of towns around Sioux Falls and Rapid City were based upon the railroad. All of this changed once Highway 16 was paved. Because of the paving of the Highway, Yellowstone National Park became far more accessible to the general public causing a steady increase in visitation from the late 1930 s onward. ${ }^{69}$

\footnotetext{
${ }^{67}$ Ibid., 448, 449-450. Even though Rough suggests that the brand for Utah was one of openness she does point out that some groups were excluded like Jewish people and members of the NAACP.

${ }^{68}$ Ibid., 454.

${ }^{69}$ Elizabeth Eiselen, "The Tourist Industry of a Modern Highway: U.S. 16 in South Dakota," Economic Geography 21, No. 3 (Jul., 1945): 224.
} 
Prior to the automobile boom of the 1950s significant importance had been placed upon the development of a highway system. As early as the 1930s economists were arguing that there was dual function of highways and that it was the government's responsibility to maintain the roads not only for safety, but for economic prosperity as well. However, the Eisenhower administration placed highway repair, construction, and funding as one of the top priorities of the fifties. Very much like the veins in the human body highways became the vessels for the life blood of American ideology and society. ${ }^{70}$

\footnotetext{
${ }^{70}$ For more on road construction of the 1930s see Shorey Peterson, "Highway Policy on a Commercial Basis," The Quarterly Journal of Economics 46, No. 3 (May, 1932): 417-443.
} 


\section{Escapism: Avoiding the Fear of the Unknown through Travel.}

In 1947 when Dwight D. Eisenhower was the Chief of Staff under the Truman administration he attempted to urge the Joint Chiefs of Staff that to prepare for all out war with foreign threats would be problematic for the United States. He was also concerned about the Truman Doctrine's outright support of all free nations who attempted to resist force from "armed minorities" or "outside pressure" (presumably Truman was referring to Communist powers). Eisenhower urged for a more subtle resistance to the Soviet threat by suggesting, "a program of preparedness that focused on 'strengthening the economic and social dikes against Soviet communism rather than...preparing for a possibly eventual, but not yet inevitable, war."' For Eisenhower the spending power and social behavior of Americans were the best defense against Communism. Part of that social behavior was to tour the country and see all that it had to offer on the road. ${ }^{71}$

When Eisenhower took office his first order of business in regards to the "Red Scare" was to develop the United States Information Agency. This was an arm of the government which ran parallel to that of the CIA in its function; essentially the USIA would enact policy rather than create it. When Communist propaganda portrayed America as a "cultural wasteland" where minorities were exploited, the USIA countered with a story where capitalism and democracy brought peace and prosperity to all. Part of the image that was created for the world of America was that all citizens owned automobiles which could be seen on

\footnotetext{
${ }^{71}$ Pach, 12.
} 
"four-laned [sic] superhighways" and Americans had "plenty of free time for leisure activities." One such activity was travel. ${ }^{72}$

According to the Eisenhower Administration and the USIA, US citizens and their capitalistic behavior were the most effective propaganda against the communist Soviet Union. The United States government created a campaign in which it suggested that through travel every American could be an ambassador for the American lifestyle. Where Americans chose to spend their money is what is of importance because they generally splurged on items that allowed them to re-enforce their American-ness and escape the general fear that lay beneath the happy façade of the 1950 s. $^{73}$

What the Eisenhower administration and the USIA did was to create a climate of fear in the United States by suggesting that Communism posed a threat to the very fundamentals of American life. By putting forth this "political fear" U.S. citizens were supposed to understand with greater significance the importance of their specific political and moral values. We are thus urged to take appropriate measures to stave off fear, specifically in the 1950 s fear of communist takeover. ${ }^{74}$

It was in the "nuclear age that the Madonna Inn and Disneyland became popular and what we view today as loud, exaggerated and somewhat obscene was a perfect respite from the political events of the 1950s. With the threat of nuclear annihilation looming over American consciousness Disneyland and

\footnotetext{
${ }^{72}$ Kenneth Osgood, Total Cold War: Eisenhower's Secret Propaganda Battle at Home and Abroad, (Lawrence Kansas: University Press of Kansas, 2006): 255-256.

${ }^{73}$ Ibid., 214-216.

${ }^{74}$ Corey Robin. Fear: The History of a Political Idea ( New York: Oxford University Press, 2004).
} 
Madonna Inn offered fantasy and predictability. Although many critics initially panned Disneyland for its "fakeness," author Ray Bradbury praised it and when discussing the crocodiles on the Jungle Boat ride he and Charles Laughton loved the plastic-ness of the experience. Different than real crocodiles, which were dangerous and lurking under the surface of the water, the Disney version was "perfect," predictable, and harmless. The plastic crocodiles of the Jungle Boat Cruise were perfect symbols for Disneyland as a whole. Disneyland was "utopian, perfected- or perfectible." Although not designed as a theme park it could be argued that Madonna Inn offers that same sense of escape when you enter the lobby that is covered in pink, boulders, and Swiss Chalet theme. ${ }^{75}$

Both resorts, Disneyland and Madonna Inn, capitalized on the new and popular mode of transportation for vacationing families in the 1950s, the automobile. The reason behind the American car of the fifties being so large was that it was a "family car" intended to help the family, including the forty-hour a week working dad, to join together in weekend excursions in a comfortable type of transportation.

In addition, the fact that both Disneyland and Madonna Inn situated themselves so close to the freeways suggests that the proprietors of both establishments intended to cash in on this type of family travel. The car allowed Americans to escape their everyday life in suburbia and the Madonna Inn also

\footnotetext{
${ }^{75}$ Karal Ann Marling, "Disneyland, 1955: Just Take the Santa Ana Freeway to the American Dream," American Art 5, No. 1/2 (Winter - Spring, 1991): 173.
} 
allowed a sense of escape, if you wanted you could be a caveman for one night in the Caveman Suite. ${ }^{76}$

The family car became the center of travel focus over train travel and was the center piece of many articles in the fifties and sixties. House and Garden featured a five page article written by a Mrs. Harper Richard who, with her husband and two children, decided not to travel by jet to some foreign location but rather took a thirty-five day, 5,400 mile road trip in their "remarkably equipped" station wagon. While most of their trip consisted of camping, the point to the article was to encourage the readers to take the family in the car and see the country at their own leisurely pace. ${ }^{77}$

By 1960 the annual amount of road travel rose to 100,000 Americans who would within a few years travel over one million miles of roads. Unlike what Madonna offered at the Inn the trend of the lodging of the 1960s was the "motor lodge" such as Howard Johnsons, Motor Lodges and Travel Lodges. The Madonna Inn did offer something that most motels were just beginning to supply guests with in 1960 which was on site dining. In fact, great numbers of restaurant chains were starting to align themselves with hotel chains in order to reap the profits from the road traveler of the decade. ${ }^{78}$

The roadside motel became so engrained in the American consciousness that fiction stories which featured the motel as the centerpiece were written for magazines. Thomas Walsh's story "Motel Weekend" tells the story of Detective

\footnotetext{
${ }^{76}$ Ibid., 176.

${ }^{77}$ Louise Parker. "Going Places, Finding Things: From Chicago to the Pacific" House and Garden 118 (July 1960).

${ }^{78}$ Arthur W. Baum, "The New American Roadside" Saturday Evening Post, 233, July 30,1960, 33.
} 
Thomas Jefferson O'Keef and his adventures at a small motel which was located by a highway just outside of Miami. Driving past the newer hotels O'Keef chose the smaller establishment because it offered free continental breakfast for two dollars and fifty cents a night. It was just this type of media, which depicted the motel as a place with potential adventure that helped to propel the road travel movement and increase the popularity of places such as the Madonna Inn. ${ }^{79}$

Analogous to Disneyland and the Madonna Inn is the Royal Pavilion in Brighton England. Initially constructed by King George IV for excursions out of London, it fell into disrepair after Queen Victoria disapproved of her uncle's lavish behavior. The Queen then sold the Pavilion to the city of Brighton who spent years repairing the building in order to allow the public to participate in a royal fantasy for a day with tours of the establishment. One could escape the drudgery of London for an afternoon, just as King George IV had, to regale in the splendor of the ocean side Pavilion. An ordinary citizen could be a king for a day. ${ }^{80}$

Fears regarding the spread of disease like influenza prompted many in the nineteenth century to frequent seaside towns such as Bath for preventative measure like drinking or bathing in the water. Issues of health and water were paramount at this time period due, in part, to the untimely death of the King Consort Albert of England. Having reportedly drunk unhealthy water at the palace the King apparently died of typhoid fever at the age of forty-two. ${ }^{81}$

\footnotetext{
${ }^{79}$ Thomas Walsh, "Motel Weekend" Saturday Evening Post, 231, February 28, 1959, 22.

${ }^{80}$ Susan Menke, "The Royal Pavilion at Brighton," British Heritage 63 Issue 3 and 6, (1985): 14. ${ }^{81}$ It has been discovered in recent years that in all likelihood Albert had a chronic illness that eventually killed him rather than typhoid fever.
} 
Because of shifting notions of the seaside during this time changes could be seen in the dimensions of these sleepy fishing towns. Bathing, which was once seen as something that could lead to disease, began to be viewed by Europeans as something that could benefit the various "humors" in the body. It was at this time that European nations began to build actual establishments dedicated to the restorative qualities of water, whether it was the ocean or fresh water sources. ${ }^{82}$

What constituted restorative health activities, such as drinking water from places such as Bath and ample rest, began to change to ideas that incorporated beliefs regarding outdoor leisure activities such as biking, hiking, rowing, fishing and hunting as well as sailing having benefits to the wellness of a body. It is here that we also see the rise in popularity in the game of golf which many resorts were beginning to incorporate into their landscape. Like their British counterparts, American seaside resorts were also extolling the healthy benefits of the sea air as well as the salt water where many activities such as swimming and surfing were arranged for guests. ${ }^{83}$

A perfect example of an upscale New England health resort of the nineteenth century was the Hygeia in Block Island, Rhode Island named for the Greek Goddess of health. Built by a physician named Charles H. Hadley who also served as an onsite doctor, Hygeia was advertised as a "haven for those seeking a healthy and comfortable vacation lifestyle."

\footnotetext{
${ }^{82}$ Garner, 86

${ }^{83}$ Bryant F. Tolles Jr. Summer by the Seaside: The Architecture of New England Coastal Resort Hotels, 1820-1950, (Hanover Ml: University Press of New England, 2002), 12.
} 
Literature touted the rest enhancing environment with running spring water in open rooms with fireplaces and endless outdoor activities for guests to engage in. Special arrangements were made to attract wealthy families who had a member who might be recovering from an illness in order to increase its visibility among the wealthy of the Eastern Seaboard. Initially the New England resort can be seen as an establishment that focused primarily on the desire to display one's level of economic prosperity, however as economic times turned downward the resorts began to focus more of their attention on the health and wellness that became a great issue for the public during the $1880 \mathrm{~s}^{84}$

In the beginning of Chapter XII of Jane Austin's book Persuasion the reader finds the heroine, Ann, and her companion Henrietta strolling along the beach at Lyme. Henrietta comments to Ann that with very few exceptions she finds that the sea air always does good, "There can be no doubt of its having been the greatest service to Dr. Shirley, after his illness, last spring twelvemonth. He declares himself, [sic] that having come to Lyme for a month did him more good than all the medicine he took..." Austen was not the only person who saw the restorative powers of the seaside resort during the nineteenth century. ${ }^{85}$

The rise in popularity of towns such as Lyme, Bath, Brighton as well as the American counterparts clearly point to a notion that leisure was not the only reason to travel. Mental and physical wellbeing were also closely linked to the vacations one took at this time. We continue to see this trend today in places such as Palms Springs where every winter people flock to take in the moderate

\footnotetext{
84 Tolles, 3, 61.

${ }^{84}$ Tolles, 9.

85 Jane Austen, Persuasion, (Toronto: Bantam Books, 1984),133.
} 
temperatures as well as the massages. The resort as we know it today was derived from seaside towns that focused on health and wellness of the body and mind.

There seems to be a few ways of viewing the Madonna Inn in reference to the historical period of 1950 s America. One could see the Inn contributing to the growing tide of family travel by car that allowed places like Disneyland and the Grand Canyon to flourish. It could also be viewed through the lens of post World War II fear of Communism. The image of the communist automatons put forth by American government-produced propaganda caused Americans to assert their independence and individuality even more, paved the way for places like the Madonna Inn. No two rooms were alike similar to the American sense of personal identity.

Furthermore, if we were to compare the Madonna Inn to the wellness resorts of the nineteenth century we see that the Madonna Inn supplied a sort of psychological wellness for the American who might have anxiety over the communist threat looming in their rear-view mirror. 


\section{$\underline{\text { Rise of the Middle Class and its Effect on the Travel Industry }}$}

For Americans the threats of nuclear destruction and Communism on their borders were not the only impetus to travel. There was also a boost in surplus income that allowed most middle class families to partake in what once was a wealthy leisure activity.

What contributed to the upsurge in leisure travel in the 1950s was the introduction of paid holiday and pay raises allowing middle income Americans more free time to travel and spend more on their vacations. Prior to the Depression in the 1930s paid vacations were limited to only salaried employees. However after World War II paid vacations became a common practice to the point that 100 percent of those within a medium income in large businesses had paid leave by 1979 . It has been noted by some economic theorists that when the economy turns downward that the middle classes tend to sacrifice travel first compared to other creature comforts such as cable. ${ }^{86}$

If placed in the same context of the British health spa of the nineteenth century we can see that the Madonna Inn fits nicely into the idea that even middle and working class citizens have an ability to sample luxury for an evening. In addition, these two types of resorts (Madonna Inn and nineteenth century European spas) allowed middle classes to dip their toes in the pools of the wealthy so to speak. If seen at either of these establishments one might be perceived as having a higher income level than one truly had.

Pierre Bourdieu examines the social implications of the judgment of taste in his book Distinction. Even though Bourdieu examines the tastes of the French

\footnotetext{
${ }^{86}$ Weiss, 318.
} 
middle class his assertion is that essentially we all display our social standing, or the social level at which we wish to be perceived, through the items we purchase and consume, "...the members of the professions have the means to realize the dispositions towards indulgence in luxury which are associated with a bourgeois origin and which are encouraged by the requirements of occupations presupposing a large accumulation of symbolic capital." 87 If we take this assertion of Bourdieu's and apply it to the traveling class middle class of the 1950s we can see very clearly how and why the Madonna Inn gained its popularity.

Although it appeared on the surface to be a luxury hotel that would allow the middle class to express that they had amassed a large quantity of disposable income, the Inn itself provided a home away from home with the warm colors (pink). Phyllis stated that the Inn strives to make the food exactly like one would make in one's own kitchen. The Madonna Inn was a perfect combination of elegance and affordability for the middle class auto traveler of the $1950 \mathrm{~s}^{88}$

Spas and resorts that rose out of post-industrialized Europe were not a new invention. Rather, there are documents that indicate that high ranking Romans traveled long distances to spas they created in places such as Turkey and North Africa. In terms of design, however, nineteenth century resorts were far superior and had many amenities that could be found in any modern European or American resort of today. The only difference between the two would be that the size and scale of resorts increased over the centuries.

\footnotetext{
${ }^{87}$ Pierre Bourdieu, Distinction: A Social Critique of the Judgment of Taste (Cambridge Mass: Routiledge and Kegan Paul Ltd. 1984), 283 \& 286.

${ }^{88}$ Phyllis Madonna, e-mail message sent to author, May 5, 2011.
} 
However, in the nineteenth century one can see a new economic class of people traveling to these seaside resorts. Eventually they became areas of social stratification and identification of wealth. ${ }^{89}$

The history of the city of Bath itself dates back prior to the Roman period when legionnaires built tiered baths in the town during the first century. After the fall of the Roman Empire the baths themselves went through stages of disrepair and revival until 1705 when Richard Nash was appointed by the city of Bath as the Master of Ceremonies. Nash fashioned an image of Bath that not only incorporated ideas of wellness, but notions of decency and proper behavior befitting the upper classes. ${ }^{90}$

Although the initial interest in the town of Arcachon on the West Coast of France was one of commercial development it became clear to some of the investors in the venture that the interest in the province as a therapeutic area was one that could be more profitable than the harvesting of the timber in the region. This prompted the company, who initially took notice of the sleepy fishing village, to turn its development more towards the idea of Arcachon as a seaside wellness retreat. The rising popularity in coastal towns as places of recuperation began to change not only the physical dimensions of these towns, but the social dimensions as well. This shared space is now perceived differently by two different groups; the locals and the visitors. ${ }^{91}$

\footnotetext{
${ }^{89}$ Margaret Huffadine, Resort Design: Planning, Architecture and Interiors, (New York, New York: McGraw Hill, 2000), 14.

${ }^{90}$ Garner, 16-19.

${ }^{91}$ lbid., 23.
} 
An example of shifting perceptions of these seaside towns is shown in the story of an unidentified French family who, in 1830, travelled to Arcachon for health of their daughter. What is important about the family's story is that the area was not just used by the family for recuperative health, but the descriptions of the area by the family include various activities that clearly did not relate to notions of health. The family wandered the shores looking for shells and occasionally traveled down to the shoreline to watch the waves (since the act of bathing usually took place in the bay itself) in addition to playing board games and reading novels. ${ }^{92}$

It was because of this shifting notion of what constituted a wellness resort that only twenty years after the unidentified family's visit that Arcachon was transformed into something that a previous visitor to the region barely recognized. By October 1859 the once sleepy fishing village became the mustsee resort town that was frequented by the likes of Napoleon III, the Empress, and the Imperial Prince of France. ${ }^{93}$

Despite vigorous exploration of the continent and England by land and canal the discovery of the seaside town and its restorative capacity was not discovered until the late eighteenth century. At this time the seaside resort was far from the thing that was frequented by completely healthy travelers in the summer months, rather it was still something to be used as a place where one could convalesce. ${ }^{94}$

\footnotetext{
92 Ibid., 89.

${ }^{93}$ Ibid., 119-120.

${ }^{94}$ Hartley Kemball Cook, Over the Hills and Far Away: Three Centuries of Holidays (London: George Allen and Unwin Ltd.,1947),120.
} 
It was only once the fashionable London upper society began to retreat to the shoreline towns such as Bath and Brighton that the notion of going to the ocean was one that encompassed not only physical well being, but mental and emotional as well. At this point middle class English saw an opportunity to advance themselves socially by taking a summer at the sea. ${ }^{95}$

These seaside towns are booming today thanks to doctors of the past extolling the benefits of the sea air. In addition to the sick, who came to resorts for health reasons, the spas saw an influx of guests who were friends and family of the invalids hoping to make a holiday out of their relative's stay. Because of this transportation and facilities improved completely changing the dimensions of these small fishing towns. It was not just the invalids that made the towns trendy, it was also those who came to support the sick that caused an influx in popularity of the towns. ${ }^{96}$

The structural design and functionality of New England resorts worked into a sense of leisure and personal wellness which was seen to be a private issue. American resort hotels were planned to provide their clients with a sense of privacy but at the same time the resorts were built in areas that were comfortable and visually pleasurable, as well as invigorating and entertaining. The resort should soothe all of one's senses and American resorts took a page directly from Europe. ${ }^{97}$

In America the Gilded Age of the late nineteenth century provided Americans with surplus spending money, and with the introduction of time saving

\footnotetext{
95 Ibid., 122, 125.

${ }^{96}$ Ibid., 134.

${ }^{97}$ Tolles, 8.
} 
inventions, surplus leisure time as well. What they did with the surplus of both was to build grand resorts at which to spend their time and display their wealth. Resorts were here transformed from sites of wellness into sites of "conspicuous consumption."98

Like its English counterpart America was geared toward consumption that allowed the middle classes to appear to be upper class and take full advantage of what little leisure time they could afford;

From private play to wholly public enjoyment, a spectrum of play grew up and was well and eagerly served, as the market for fashionable leisure and its accoutrements expanded over the eighteenth century. The whole continuum hinged on consumption: the purchase, not merely of things, but of leisure itself. ${ }^{99}$

The "middling sort," were responsible for a large portion of the leisure economies of places such as Bath and the town itself began to build up it economy based upon these frequent visitors. It is with towns like Bath that one begins to see the development of a "vacation town" which spends three to four months of a year building up its economy for the rest of the year.

The notion of physical health was not the only attraction to many of these seaside towns. Social interaction was also considered beneficial to a healthy mind which in turn would lead to a healthy body. The social nature of the spa, particularly with relation to middle class English women, further changed the dimensions of the European resorts. The resorts such as Bath and Brighton in England provided not only a heterosexual meeting place where one might court

\footnotetext{
${ }^{98}$ Susan R. Braden, The Architecture of Leisure: The Florida Resort Hotels of Henry Flagler and Henry Plant (Gainesville, Florida: University Press of Florida, 2002), 40-42.

${ }_{99}$ Janet E. Mullin, "Cards on the Table: The Middling Sort as Suppliers and Consumers of English Leisure Culture in the Eighteenth Century" Canadian Journal of History, (Spring/ Summer 2010): 51-52.
} 
and find a mate, but also a social setting for women that was acceptable among society and could be defined as their own. ${ }^{100}$

In terms of a meeting place of the sexes to solidify unions, in the eyes of English society, nothing could be healthier. The notion of producing offspring of a certain social level was of vital importance to the general health of the nation as well as the health of the upper classes. To prevent a seeping in of undesirable people, i.e. the poor, the wealthy needed a place where they could seek out those of the same ilk in order to produce proper heirs. ${ }^{101}$

Documentation provided by Bluestockings ${ }^{102}$ describes the watering place as the best place in the world for women's conversation and by doing so proclaimed the spa to be a community held domain. By repeatedly suggesting that friends partake in the leisure activity of traveling to the spa the Bluestockings asserted women's rights to access this domain. For women, who were very rarely included in the social endeavors of their mates and were usually left on their own while in the cities or at their country estates, the resort towns provided an arena where women could safely gossip, engage in tame social activities such as walks along the shore with companions or shopping in town. ${ }^{103}$

In addition to providing a place to socialize it also provided women something to socialize about when they were home. The letters that have been collected by Hurley clearly show that the desire of most of these women is to either discuss what has occurred in these seaside resorts during the vacation

\footnotetext{
${ }^{100}$ Alison E Hurley, "A Conversation of Their Own: Watering-Place Correspondence Among the Bluestockings," Eighteenth-Century Studies 40, Number 1, (Fall 2006): 1-21.

101 lbid., 3.

102 This is the term used to describe middle to upper class British ladies.

${ }^{103}$ Ibid., 9.
} 
season or to regain a sense of the feeling they had while in the company of other women of similar station. The spas allowed women to discuss something that was outside the normal scope of discussion for homebound social elite. ${ }^{104}$

Eventually the purpose of a town such as Bath was not just to take in the healthy water (which had questionable taste) but to socialize with the upper society that frequented such a place. Writing in February 1786 a gentleman named Hugh Elliot suggested that Bath was the most pleasant town he had ever had the pleasure of visiting and it wasn't simply because of the lovely streets and public buildings. Elliot states that although he did not care much for society life he was forced to admit there were a great number of "fair Hybernian nymphs with the most splendid shapes" on display at the dance halls at night that caught his attention. English resort towns were not however the only resorts that had this type of dual functionality. ${ }^{105}$

On the continent European resorts began to monopolize on the growing fashions of the time. Places such as Mirenbad and Baden-Baden featured not only spas that were geared at attracting the health fanatic, but also contained gambling casinos which catered to the wealthy. The rich frequented resorts that would meet their demands for "a sunny place, sedative, but not depressing, comfortable, good food, lively, interesting and convenient."106 This description could be taken from a pamphlet of a modern resort of Europe that people frequent today.

\footnotetext{
104 Ibid., 9.

${ }_{105}^{105}$ Cook, 104.

${ }^{106}$ Ibid., 104
} 
Resorts can be said to have provided a dual capacity for guests. Resorts not only allowed vacationers to rejuvenate their senses through massage, mud baths, and pinã coladas by the pool, but they also allowed them to socialize in a setting that did not incorporate any of the daily distractions such as work or family. In addition, these social settings displayed a level of opulence that gave the visitor a sense of self-importance or allowed the visitor to assimilate into a social class that may have not necessarily been their own.

Whole books are devoted to the notion of spas and resorts, such as the recent The World's Greatest Hotels, Resorts and Spas which looks at 134 resorts worldwide. Based upon customer reviews and the editors' own personal experience the authors have tabulated the best places to relax world wide. One such resort is the Arizona Inn in Tucson where a nightly rate can cost a visitor anywhere from $\$ 199$ for a standard room to upwards of $\$ 500$ dollars for a deluxe suite. One can check into any number of Tucson's health resorts, "but since 1930, those in search of glamour have headed straight to the Arizona Inn" so not only does it cover one's spa needs, but the resort feeds into a sense of glamour that we all apparently desire. ${ }^{107}$

The same sort of glamour could and still can be found at the Madonna Inn. When guests range from Paul Newman, Joan Woodworth and John Wayne or William Randolf Hearst Jr. the average guest can capture as sense of worth and importance even if one has a median income. When asked why she felt that people still seemed to be captivated by the Inn today Phyllis Madonna stated,

\footnotetext{
${ }^{107}$ Laura Begley, Irene Edwards, Peter John Linberg and Meeghan Truelove ed. Travel and Leisure: The World's Greatest Hotels, Resorts and Spas Fourth Edition, (New York, New York: American Express Publishing Corporation, 2008), 35.
} 
"The ambiance and warmth and happy feeling when you enter the front doors attracts people to the Inn... We have always tried to achieve comfort, peace and happiness to all of our guests as soon as they enter the front door." ${ }^{\text {"108 }}$ It is that warm happy feeling of being treated like a king or a queen for a day surrounded by gilded cherubs that consistently kept and keeps visitors traveling to the Madonna Inn.

\footnotetext{
${ }^{108}$ Phyllis Madonna, e-mail message sent to author, May 5, 2011.
} 


\section{$\underline{\text { Conclusion }}$}

Current trends in the historiography of hotels lean towards the examination of the architect of the structure or the interior designer of a hotel. For example, some historians take particular art popular during a time period (such as art deco) and apply it to the hotel's overall design. Another trend focuses on the guests who frequented a hotel to understand the historical importance of a structure. There are also authors who speculate on how a particular resort economically changed the dynamics of a town to point to the hotel's significance.

Finally there are historians who look at the life stories of the establishment's owners to explore the deeper significance behind why a hotel was built the way it was. These authors feel that if the personal traits, likes or dislikes of a property owner are elucidated that the reader can come to understand why a particular color in the lobby was used or why the owner chose to use wood or stone in the floor. ${ }^{109}$ The aim of this paper is not to discredit these authors' attempts, but to argue that some traumatic event in the owner's life caused him to pick a particular interior design leans towards a reductionist argument that can become problematic.

If, however, one were to look at the Madonna Inn through the lens of an artistic movement the Folk Art or Outsider Art movement of the 1950s is best suited for the Madonna Inn. Alex Madonna did not follow any particular style, rather he combined images and themes that were pleasing to his own sense of

\footnotetext{
${ }^{109}$ Braden, Susan R. The Architecture of Leisure: The Florida Resort Hotels of Henry Flagler and Henry Plant (Gainesville, Florida: University Press of Florida, 2002).
} 
art. Very much like the Outsider artists, Alex Madonna followed his own vision of what was fashionable, albeit a pink vision, but a vision none the less.

It is imperative when examining the history of a building that not only the interior but the exterior be examined both figuratively and metaphorically speaking. To understand how the Madonna Inn came to fruition with its bright pink colors and what Paul Lukas called the "oddest lodging" on the Central Coast and "famously kitschy", one must first examine the perfect storm of exterior forces that came together to help create the image in Madonna's mind. ${ }^{110}$

The growing economy allowed the federal government to spend money on the construction of roads and highway projects which in turn allowed Madonna to make money and spend it on his dream creation, the Madonna Inn, "There is a deeper similarity to Disneyland. Like Walt Disney, Alex Madonna has created a toy to please himself." ${ }^{111}$ Similar to the rest of America during the 1950 s Madonna spent money on what pleased him.

The American population spent money on leisure items such as travel to places such as Disneyland and Madonna Inn to alleviate the ever growing oppressive fear of Communist take-over and nuclear war. Similarly the U.S. government spent money on highway construction in order to encourage travel and thus create the image of a stable, functioning, capitalistic society that was capable of handling any threat the Soviet Union might send their way.

This was not the only instance when a combination of various historical events occurred. During the nineteenth century technological advances,

\footnotetext{
${ }^{110}$ Paul Lukas, "Toast of the Coast", Money 32 Issue 8, Aug 2003, 134.

${ }^{111}$ Harmetz,1.
} 
increased spending of the middle class and an unspoken fear of disease led to the popularity in resorts and resort towns such as Brighton and Bath. In the 1950s highway construction, spending by both the U.S. government, and the general population, and unspoken fears of the imagined enemy came together to generate the perfect conditions for the Madonna Inn to flourish. What is historically important to understand about Madonna and his influence on the wonderland that he constructed is that his decisions were not made in a void and therefore his building should not exist in one. There were a multitude of events culturally, economically and in the world of technology that lead to the development as well as the popularity of the Madonna Inn.

Madonna was affected by the job he had in highway construction, by the time period of desired fantasy he build in and by the economic setting that existed in the country at the time. Because of that his influences are seen in the building that Lily Koppel said was, "Reminiscent of the board game Candyland, it is doused in Pepto-Bismol pink. Everything from the street lights to the vending machines is painted in that shade, which the couple thought set a romantic mood for honeymooners." 112 And like a board game Madonna played with colors, materials, and mixed themes to make a home away from home that was unlike any home that anyone could possibly imagine.

\footnotetext{
${ }^{112}$ Lily Koppel, "Alex Madonna, 85, Creator of a Memorable and Colorful Inn," New York Times, April 26, 2004.
} 
"Anybody can build one room and a thousand like it," says Mr. Madonna, from the booth he occupies in the dining room every evening. "It's more economical. Most places try to give you as little as possible. I try to give people a decent place to stay where they receive more than they are entitled to for what they're paying. I want people to come in with a smile and leave with a smile. It's fun. What fun do you think Paul Getty got out of life? What fun did the Hunt boys have from their silver?...." Alex Madonna ${ }^{113}$

\footnotetext{
${ }^{113}$ Harmetz, 1.
} 


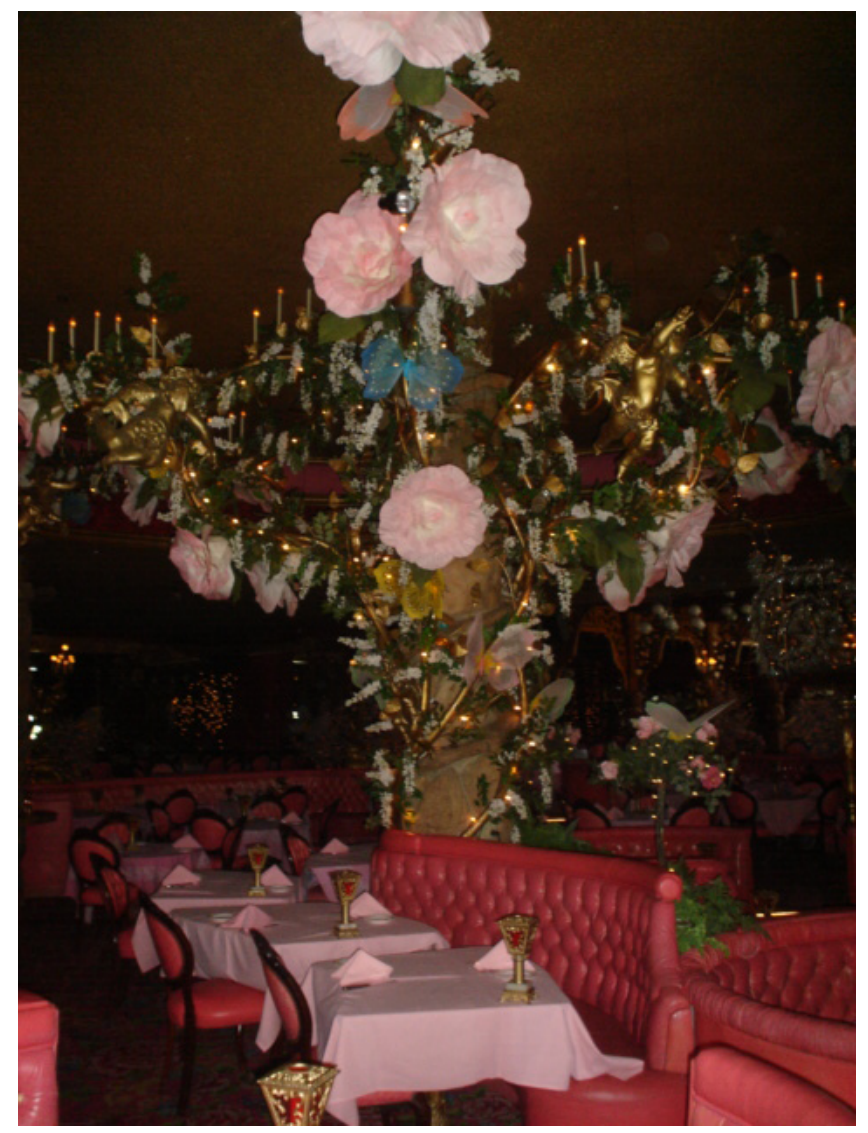

Image F2 : The tree light fixture in the Gold Rush Steak House created out of recycled material. Here the decorations are for the summer season.

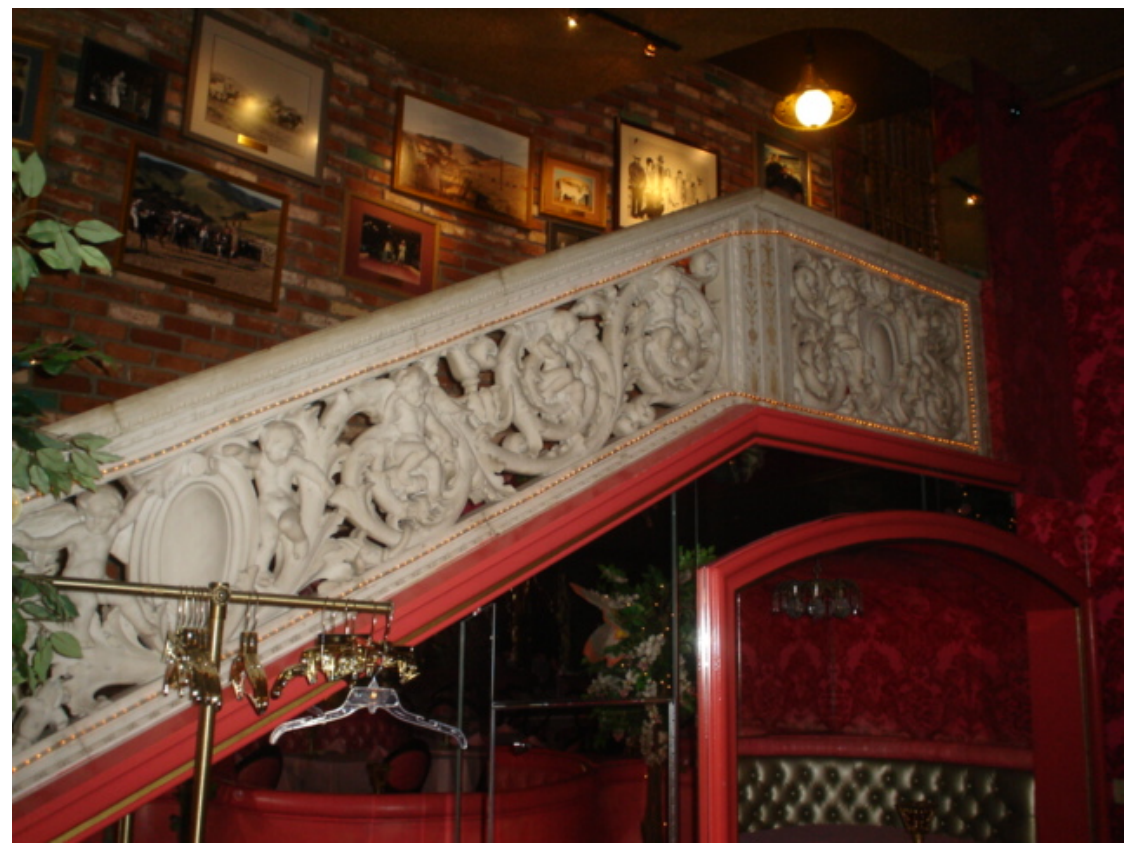

Image F3: The marble balustrade in the Madonna Lobby given to Alex Madonna by the Hearst Family. 


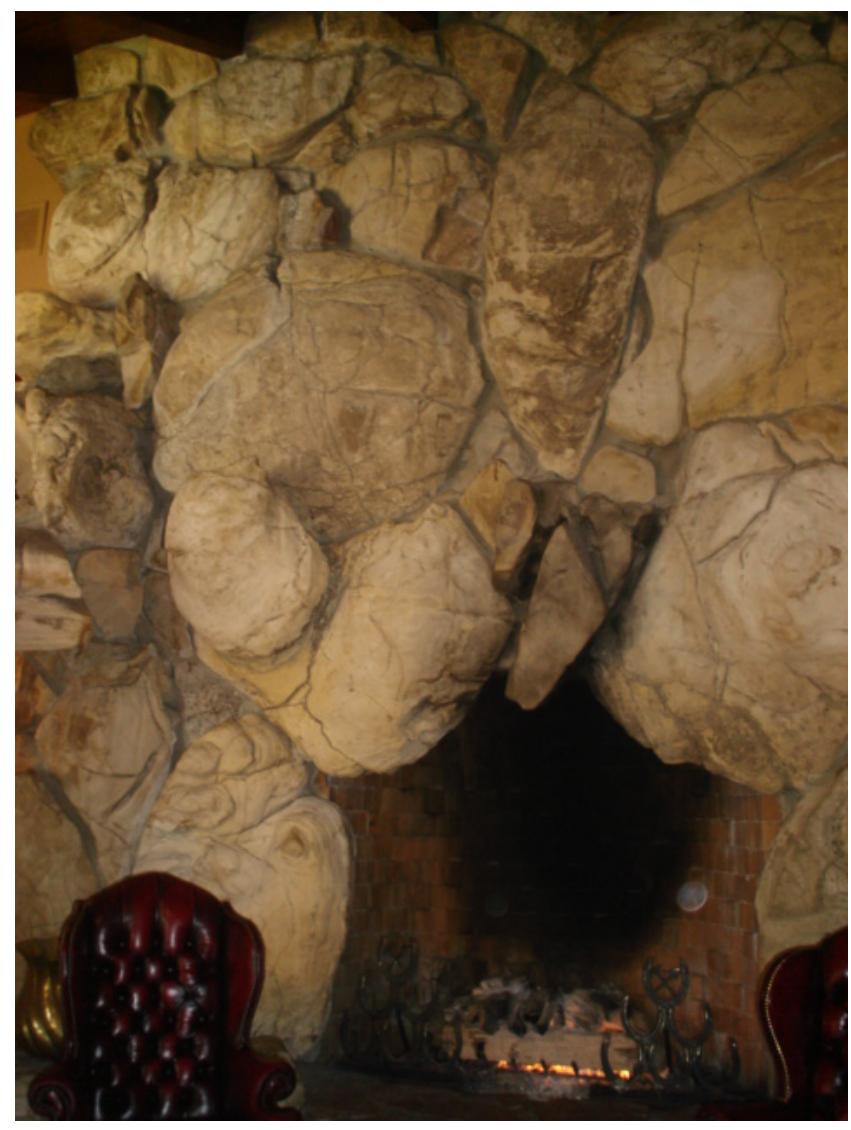

Image F4 : Local boulders used to construct the fireplace in the entryway of the Madonna Inn.

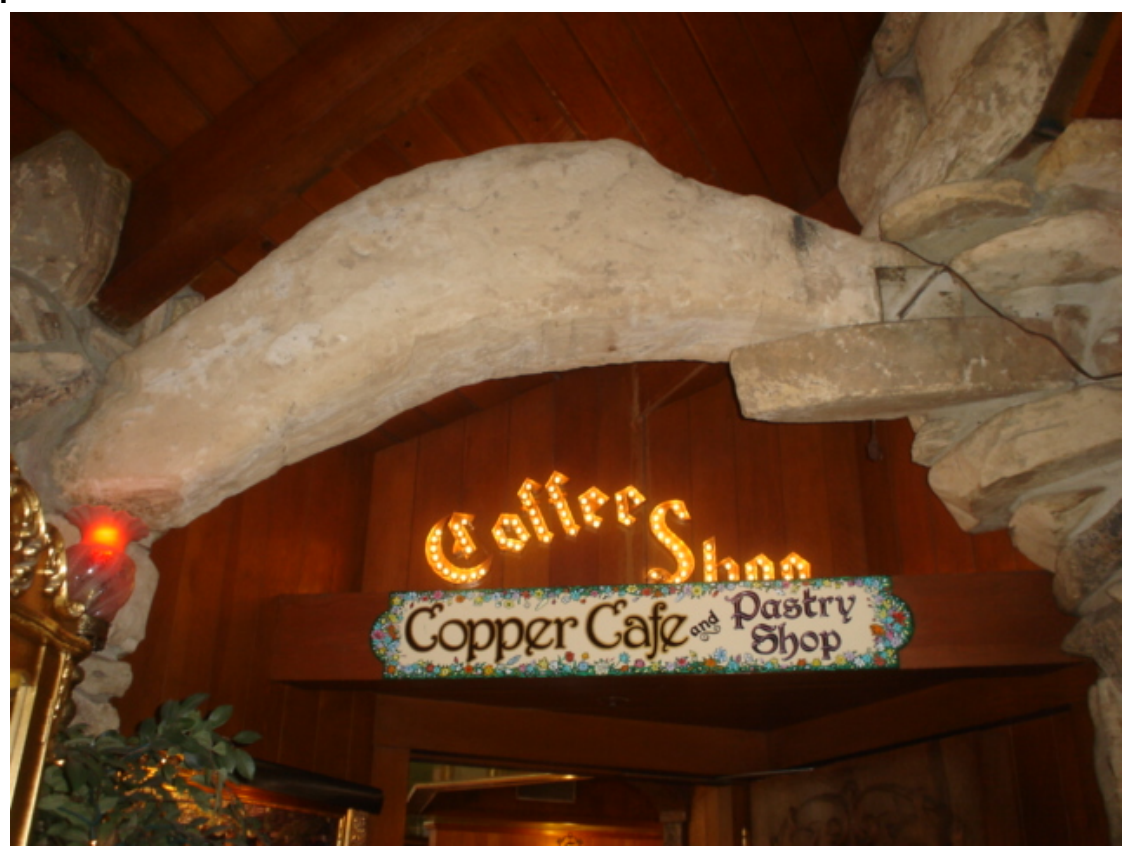

Image F5 : The cantilevered rock above the Copper Café. 


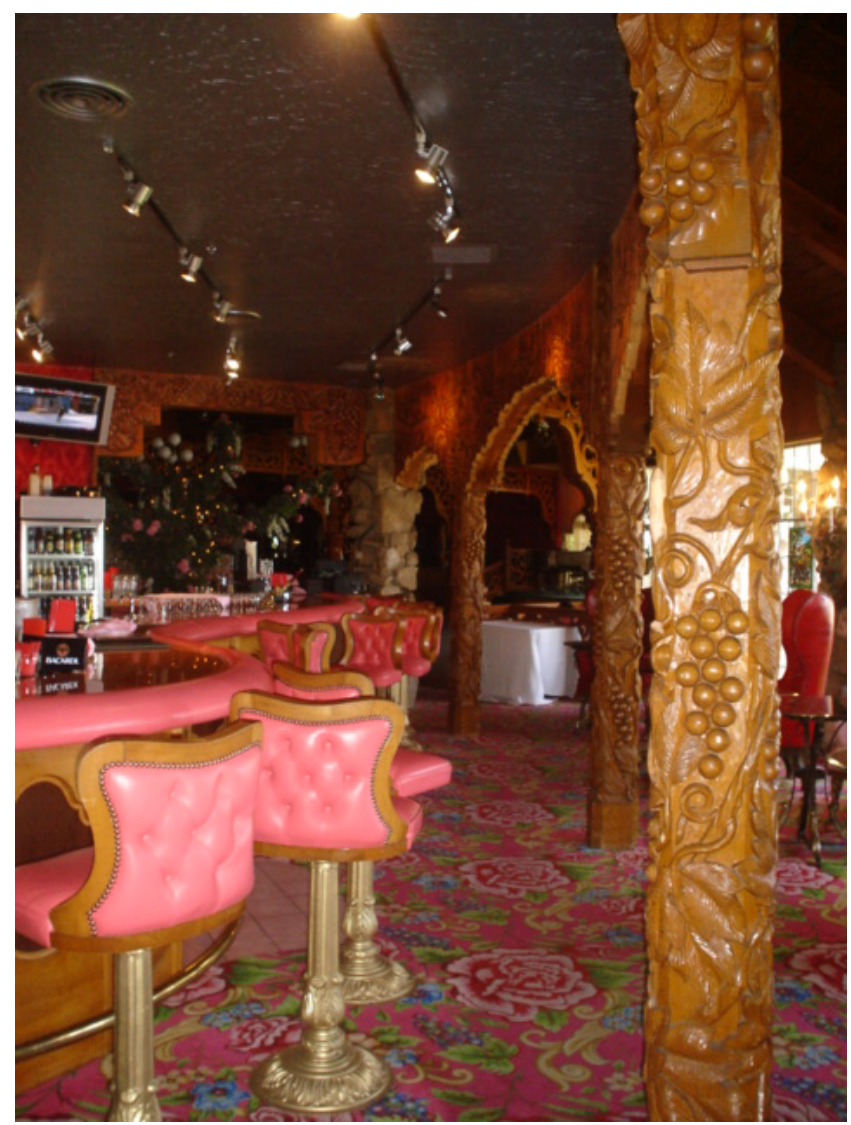

Image F6: Example of the woodwork in the bar of the Madonna Inn which was constructed on site by Alexander Zeller.

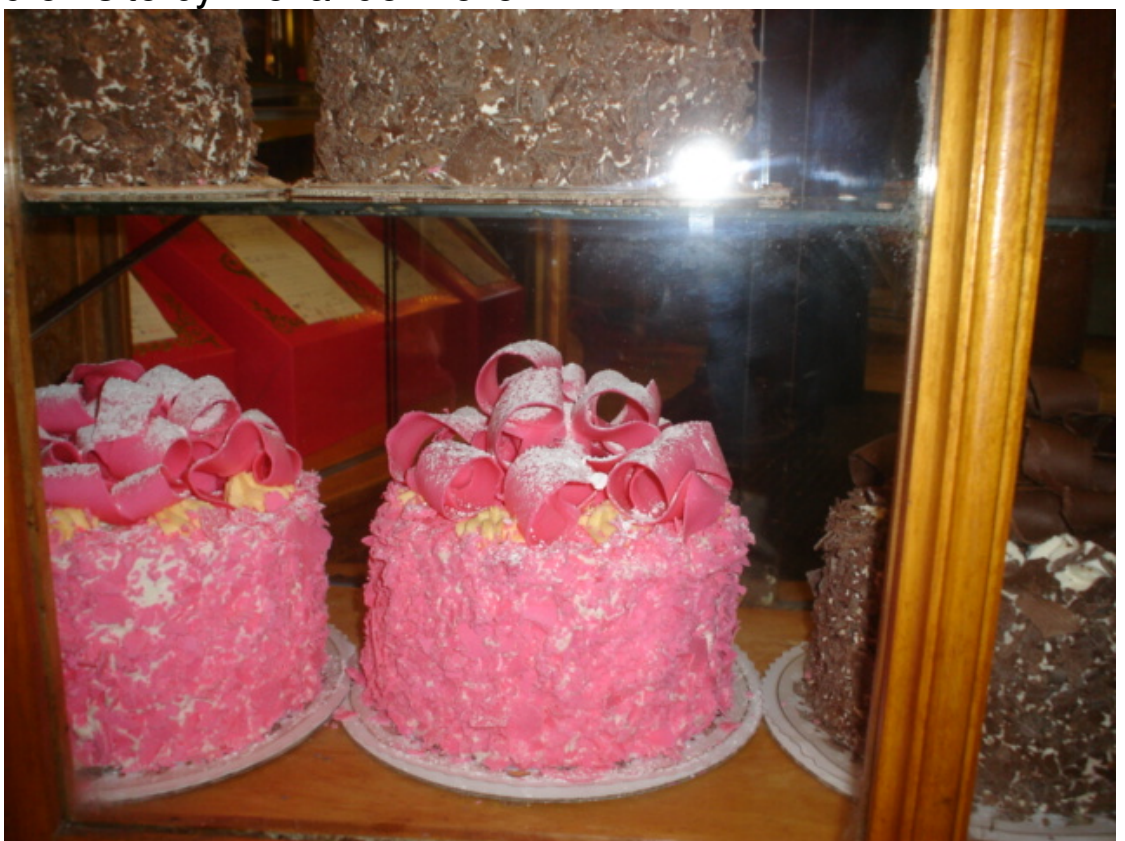

Image F7: The Pink Champagne Cake of the Madonna Inn and directly to the right a partial view of the Black Forest Cake. 


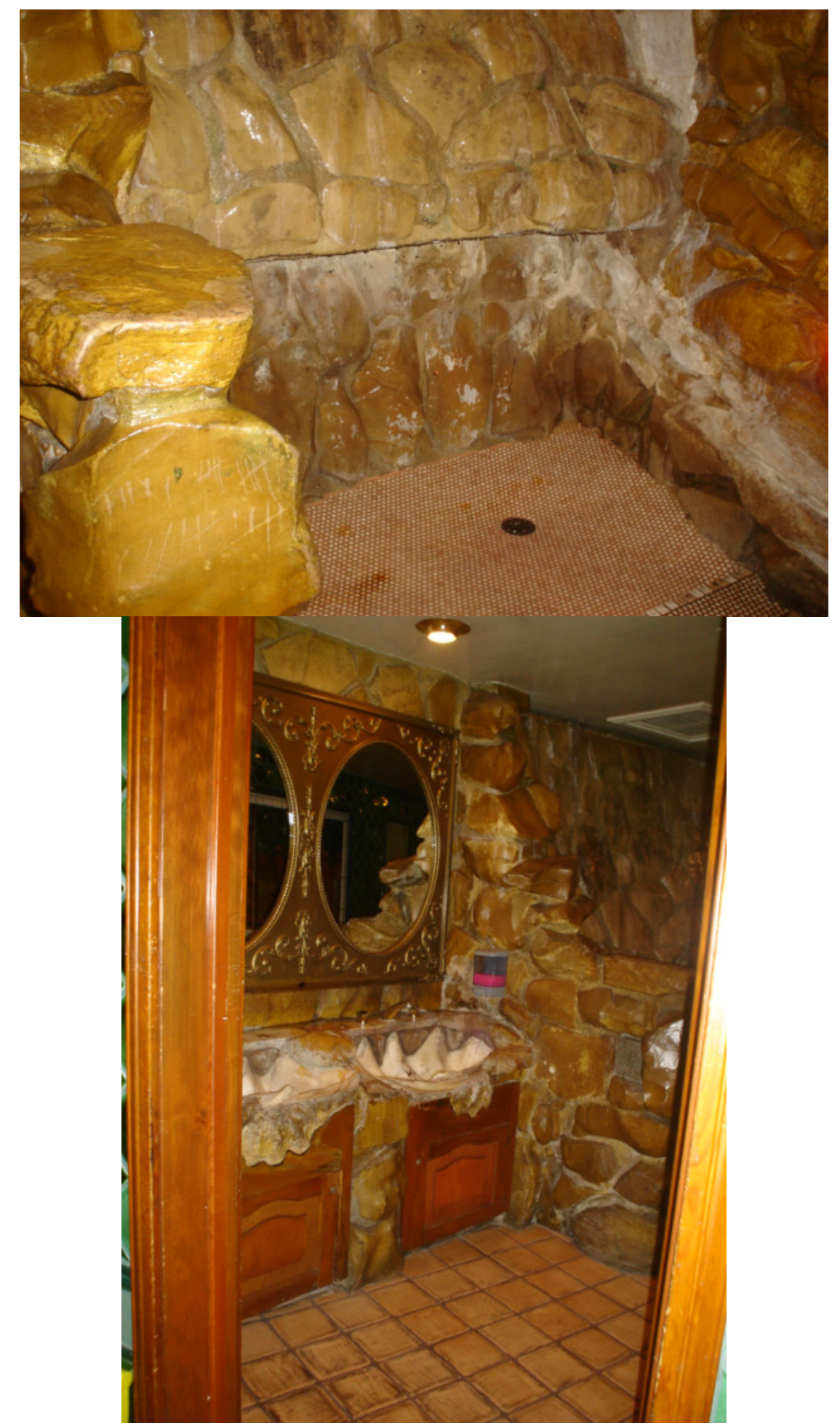

Images F8 and F9:The world famous men's bathroom in the wine cellar which features the waterfall urinal and sea shell wash-basins. 


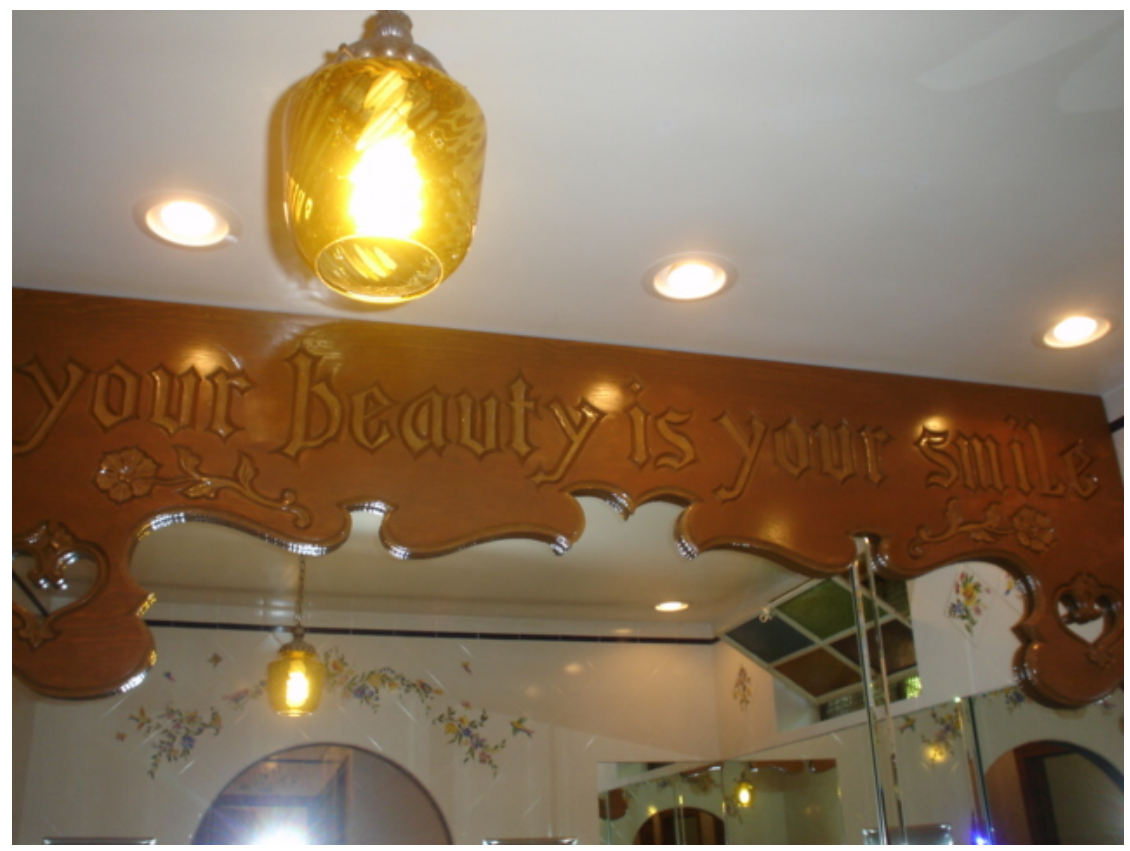

Image F10 : The woodwork in the women's bathroom of the Copper Coffee Shop which states "your beauty is your smile" above the mirror.

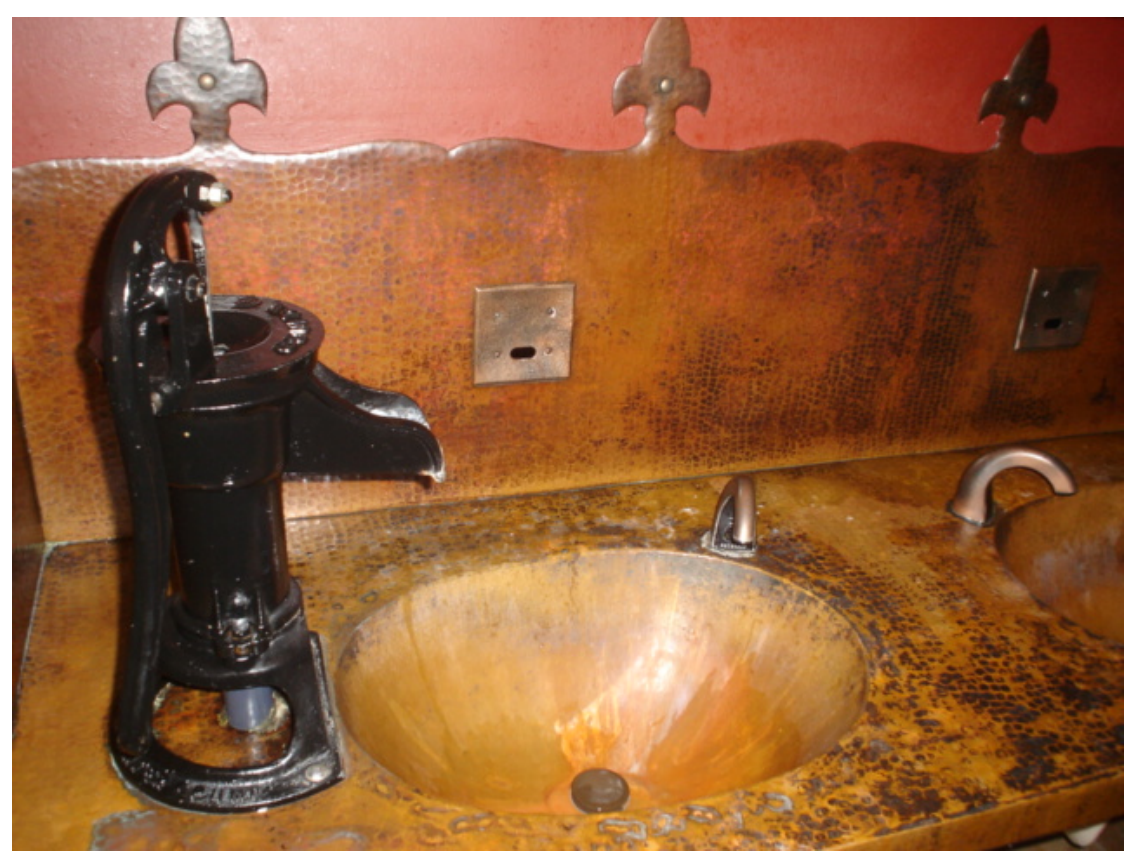

Image F11: The copper sink and water pump in the men's bathroom of the Copper Coffee Shop. 


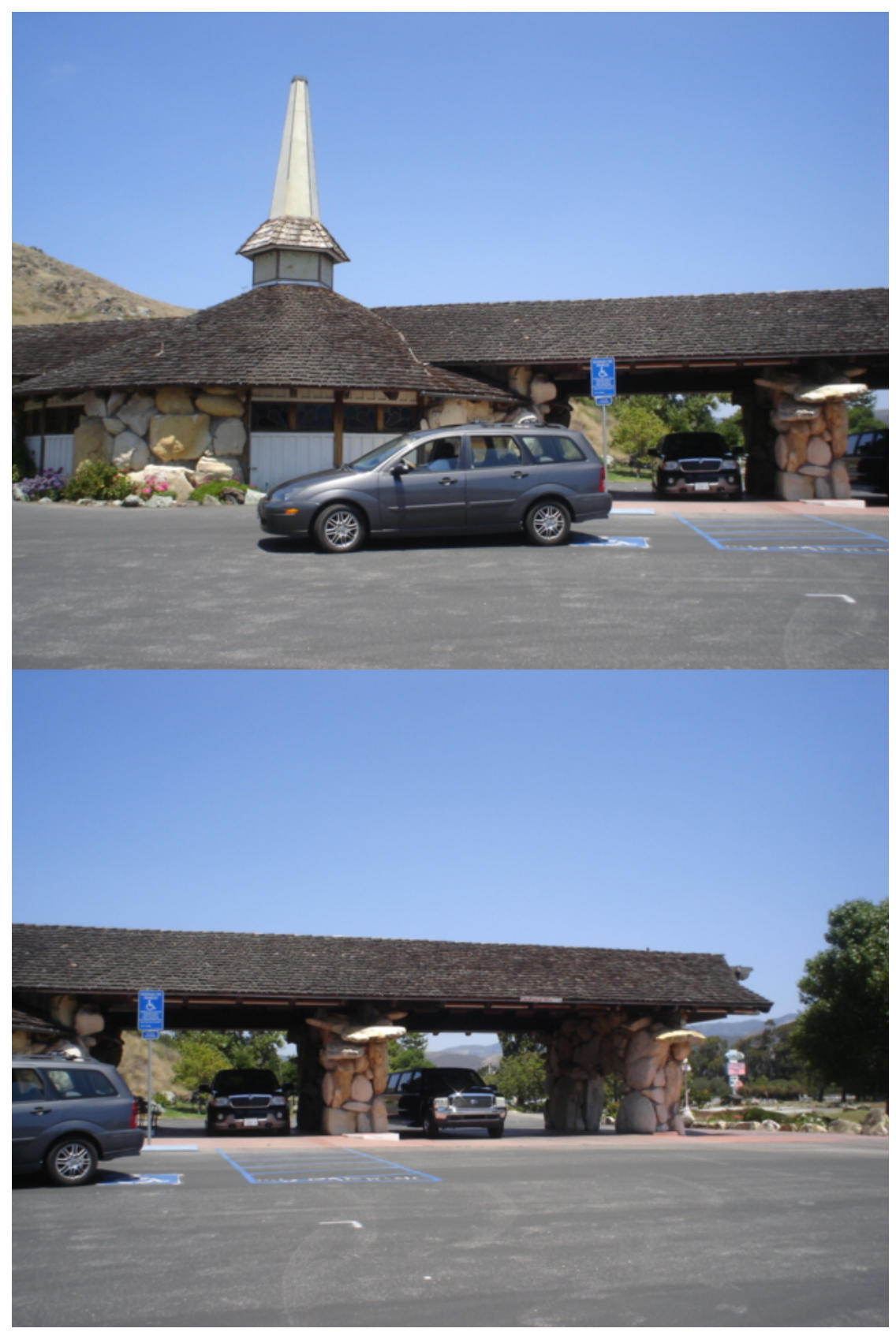

Images F12 and F13: The former 76 Union Oil Company gas station at the Madonna Inn. Currently the building houses a gourmet wine and gift shop.

Images of the Madonna Inn taken by Jeremiah and Galadriel Bree Highhouse 2011 @ 


\section{Bibliography}

Abbot, Philip. "Eisenhower, King Utopus, and the Fifties Decade in America." Presidential Studies Quarterly (March 2002): 7-29.

Alper, Nicole. "Adventures for Two." Essence (Time Inc.), 38 Issue 3, July 2007.

Arnold, Vivien. "The Image of the Freeway." JAE 30, No. 1, Teaching the Landscape (Sep., 1976): 28-30.

Austen, Jane. Persuasion. Toronto: Bantam Books, 1984.

Batchelor, Denzil. The English Inn. London: B.T. Batsford Ltd, 1963.

Baum, Arthur W. "The New American Roadside." Saturday Evening Post 233, July 30,1960 .

Begley, Laura, Irene Edwards, Peter John Linberg and Meeghan Truelove ed. Travel and Leisure: The World's Greatest Hotels, Resorts and Spas Fourth Edition. New York, New York: American Express Publishing Corporation, 2008.

Berger, Molly W. Hotel Dreams: Luxury, Technology and Urban Ambition in America 1829-1929. Baltimore, Maryland: John Hopkins University Press, 2011.

Bottoms, Greg. The Colorful Apocalypse: Journeys in Outsider Art. Chicago, Illinois: University of Chicago Press, 2007.

Bourdieu, Pierre. Distinction: A Social Critique of the Judgment of Taste. Cambridge Mass: Routiledge and Kegan Paul Ltd. 1984.

Braden, Susan R. The Architecture of Leisure: The Florida Resort Hotels of Henry Flagler and Henry Plant. Gainesville, Florida: University Press of Florida, 2002.

Branyan, Robert L. and Lawrence H. Larsen. The Eisenhower Administration 1953-1961 a Documentary History. New York, New York: Random House, 1971.

Braudel, Fernand. Wheels of Commerce. New York : Perennial Library, 1982.

Brennan, John. "Madonna: The Man and the Inn." Senior Project, California Polytechnic University of San Luis Obispo, 1971.

Brooks, Timothy. Vermeer's Hat: The Seventeenth Century and the Dawn of the Global World. London:Profile Books Ltd., 2009. 
Carlin, Martha. "What Say You to a Piece of Beef and Mustard?: The Evolution of Public Dining in Medieval and Tudor London." The Huntington Library Quarterly: (2008):1-19.

Committee on Transportation and Infrastructure. "Celebrating 50 Years: The Eisenhower Interstate Highway System." United States Printing Office (2004):168.

Cook, Hartley Kemball. Over the Hills and Far Away: Three Centuries of Holidays. London: George Allen and Unwin Ltd.,1947.

Coulter, John Wesley. "San Luis Obispo." Economic Geography, 7, No. 3 (July, 1931): 308-318.

Craigmoe, Peter ed. "Alex Madonna: Innkeeper Extraordinary." Seventy Six Union Oil Company of California, May/June 1970.

Cubbs, Joanne. "Rebels Mystics and Outcasts: The Romantic Artist Outsider." in The Artist Outsider: Creativity and the Boundaries of Culture, edited by Michael D. Hall and Eugene W. Metcalf Jr., Washington D.C.: Smithsonian Institution Press, 1994.

Davis, Susan. "Tourism in Southern California." Pacific Historical Review, 68, No. 2, Orange Empires (May, 1999): 173-191.

Eco, Umberto. Travels in Hyper-Reality. Orlando Florida: Harcourt Inc, 1986.

Eiselen, Elizabeth "The Tourist Industry of a Modern Highway: U.S. 16 in South Dakota" Economic Geography, 21, No. 3 (Jul., 1945): 221-230.

Franks, Janet Penn. Images of America San Luis Obispo a History in Architecture. San Francisco: Arcadia Publishing 2004.

Garner, Alice. A Shifting Shore: Locals, Outsiders, and the Transformation of a French Fishing Town 1823-2000. Ithaca, New York: Cornell University Press, 2005.

Gutfreund, Owen D. $20^{\text {th }}$ Century Sprawl: Highways and the Reshaping of the American Landscape. New York, New York: Oxford University Press, 2004.

Hackwood, F.W. Inns, Ales and Drinking Customs of Old England. London: Bracken Books Publishing, 1909.

Hall, Michael D. and Eugene W. Metcalf Jr. ed. The Artist Outsider: Creativity and the Boundaries of Culture. Washington D.C: Smithsonian Institution Press, 1994. 
Harmetz, Aljean. "California's Oddball Hotel." The New York Times, January 3, 1982.

Hay, Douglas. Albion's Fatal Tree: Crime in $18^{\text {th }}$ century England. London: A Lane Publishing, 1975.

Hotel del Coronado Collection, Volume 203 Special Collections and University Archives, San Diego State University.

Huffadine, Margaret. Resort Design: Planning, Architecture and Interiors. New York, New York: McGraw Hill, 2000.

Hurley, Alison E. "A Conversation of Their Own: Watering-Place Correspondence Among the Bluestockings." Eighteenth-Century Studies, 40, Number 1, (Fall 2006): 1-21.

Koppel, Lily. "Alex Madonna, 85, Creator of a Memorable and Colorful Inn," New York Times, April 26, 2004.

Lachman, Richard. "Origins of the Capitalism in Western Europe: Economic and Political Aspects." Annual Review of Sociology 15 (1989): 47.

Lambert, Richard S. The Fortunate Traveler: A Short History of Touring and Travel for Pleasure. New York: Andrew Melrose Ltd, 1950.

Lukas, Paul. "Toast of the Coast." Money 32 Issue 8, Aug 2003.

Lynem, Julie and Carol Roberts. "True Original; Thousands Turn Out to Pay Tribute to One of the Most Influential and Charismatic Personalities San Luis Obispo County has Ever Known." Telegram Tribune, April 30, 2004.

Madonna, Phyllis. Madonna Inn: My Point of View. San Luis Obispo: Pick and Shovel Publishing, 2002.

Madonna, Phyllis. E-mail message sent to author on May 5, 2011.

Marling, Karal Ann. "Disneyland, 1955: Just Take the Santa Ana Freeway to the American Dream." American Art, 5, No. 1/2 (Winter - Spring, 1991):168-207.

Menke, Susan. "The Royal Pavilion at Brighton" British Heritage, 63 Issue 3,6, (1985):12-23.

Mittelstaedt, Alan. "Bold Madonna Plan; Alpine Village Envisioned on Peak." Telegram Tribune, (no date).

Mooney, Bel. "California Dream." The Guardian, May 22, 2004. 
Mullin, Janet E. "Cards on the Table: The Middling Sort as Suppliers and Consumers of English Leisure Culture in the Eighteenth Century." Canadian Journal of History, (Spring/ Summer 2010): 49-81.

Osgood, Kenneth Total Cold War: Eisenhower's Secret Propaganda Battle at Home and Abroad. Lawrence Kansas: University Press of Kansas, 2006.

Pach, Chester J. Jr. and Elmo Richardson. The Presidency of Dwight D. Eisenhower. Lawrence Kansas: University of Kansas Press, 1991.

Papanek, Victor. "The Function of Beauty" in Beauty is Nowhere: Ethical Issues in Art and Design, edited by Richard Roth and Susan King Roth. Amsterdam Netherlands: G\&B Arts International, 1998.

Parker, Doug. "On Spic-and-Span Patrol at the Madonna Inn." Telegram Tribune, July 20,1985.

Parker, Louise. "Going Places, Finding Things: From Chicago to the Pacific." House and Garden, 118, July 1960.

Peterson, Shorey. "Highway Policy on a Commercial Basis." The Quarterly Journal of Economics, 46, No. 3 (May, 1932): 417-443.

Pearce, Clint. E-mail message sent to author November 19, 2011.

Robin, Corey. Fear: The History of a Political Idea. New York: Oxford University Press, 2004.

Robinson, W.W. The Story of San Luis Obispo County. Los Angeles: Title Insurance and Trust Company Ca., 1957.

Rough, Susan Sessions. "Branding Utah: Industrial Tourism in the Postwar American West." The Western Historical Quarterly, 37, No. 4 (Winter, 2006): 445472.

Sandoval-Strausz, A.K. Hotel: An American History. New Haven, Conn: Yale University Press, 2007.

Schivelbusch, Wolfgang. Taste of Paradise: A Social History of Spices, Stimulants and Intoxicants. New York: Vintage Books, 1992.

Sloan, Gene, Kitty Bean Yancey and Jennifer Vishnevsky. "Sit Down and Stay a While in These Stylish Restrooms." USA Today, April 2005. 
Tolles, Bryant F. Jr. Summer by the Seaside: The Architecture of New England Coastal Resort Hotels, 1820-1950. Hanover, Ml: University Press of New England, 2002.

Walsh, Thomas. "Motel Weekend." Saturday Evening Post, 231 (February 28, 1959).

Warren, Glenda. Interview conducted on October 10, 2011.

Weiss, Thomas. "Tourism in America before World War II." The Journal of Economic History 64, No. 2 (Jun. 2004): 280-327.

Winslow, Carleton M Jr. Discovering San Luis Obispo County. San Luis Obispo: No Publisher, 1971.

Withers, Audrey ed. "Eight Attractive Places to Eat and Sleep in United States Coast to Coast." Vogue (August 1960). 